$1-1-1900$

\title{
The periodical cicada or seventeen-year locust in West Virginia
}

\author{
A. D. Hopkins
}

Follow this and additional works at: https://researchrepository.wvu.edu/ wv_agricultural_and_forestry_experiment_station_bulletins

\section{Digital Commons Citation}

Hopkins, A. D., "The periodical cicada or seventeen-year locust in West Virginia" (1900). West Virginia Agricultural and Forestry Experiment Station Bulletins. 68.

https://researchrepository.wvu.edu/wv_agricultural_and_forestry_experiment_station_bulletins/68 @ WVU. It has been accepted for inclusion in West Virginia Agricultural and Forestry Experiment Station Bulletins by an authorized administrator of The Research Repository @ WVU. For more information, please contact ian.harmon@mail.wvu.edu. 
Digitized by the Internet Archive in 2010 with funding from

Lyrasis Members and Sloan Foundation 


\section{WEST VIRGINIA UNIVERSITY \\ AGRICULTURAL EXPERIMENT STATION, \\ MORGANTOWN, W. VA.}

Bulletin 68.

SEPTEMBER, 1900.

\section{THE PERIODICAL CICADA OR SEVEN-}

\section{TEEN-YEAR LOCUST IN}

\section{WEST VIRGINIA.}

A REVision OF BULletin 50, AND INCLUDiNg additional data, WITH REFERENCE TO THE 1898 AND 1900 SWARM OF THE INSECT.

BY A. D. HOPKINS, PH. D. 


\section{THE REGENTS OF THE WEST VIRGINIA UNIVERSITY.}

NAME OF RKGENTS.

Hon. George C. Sturgiss

Hon. James F. Brown

Hon. A. H. Kunst

Hon. Richard Randolph McMahon

Hox. Johi J. Davis

Hon. James L. Hamili,

Hon. John A. Campbell.

Hon. W. E. Powell

Hon P.C Eastham .
P. O. ADDRESS.

Morgantown

- Charleston

- Weston

- Harper's Ferry

Clarksburg

Welch

New Cumberland.

Parkersburg Pt. Pleasant

\section{STATION COMMITTEE.}

George C. Sturgiss.

James L Hamill.

James F. Brown.

President Regents

Geo. C. StTurgiss

President University - Jerome H. Raymond, A. M., Рн. D

Treasurer

A. R. Whitehill, Ph. D.

Audito

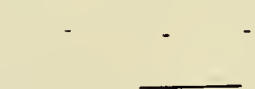

STATIUN STAFF.

Janes H Stewart, A. U,

A. D. Hopkins, Ph. D.,

Beit H Hith, M. S.,

L. C. Conветт, M. S.

W. E. RUAistr, B. S. Agr.

IIORACE ATWOOD, M. S

C. D. Howalid, B. S.

E. C. FRANE

M A. STEWART -
Director and Agriculturis: Vice Directoi and Entomologist Chemist - Horticulturist Assistant Entomologist - Assistant Agriculturist Assistant Chemist - Clerk and Stenographer Librarian 



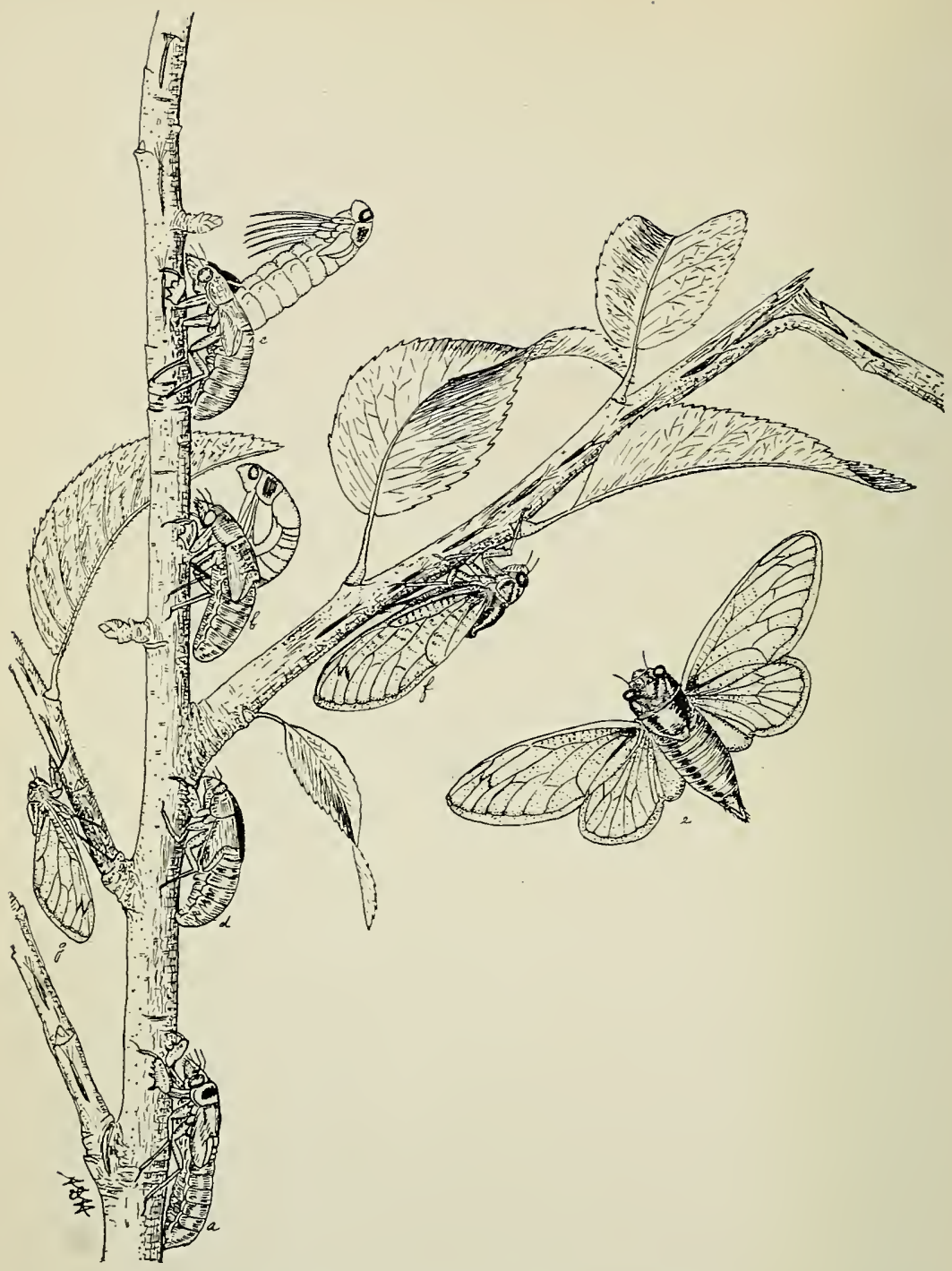

The Periodical Cicada, (Cicada septendecim.

a. pupa; $b$, pupa with back split open and adult coming out; $c$, the same with adult almost out; $d, \in m p t y$ pupa shell; $e$, adult wings spread; $f$. adult iemale in act of ovipositing $; g$, dwarf variety, showing comparative size. All about two-thirds natural sizes. ( $b$ and $c$ after Riley.) 
을을

o :

क

$\exists=\frac{2}{=}$

3.

点 之

를

을

है

독

평

里

음

$\circ$ ㅇ․

ㅇ․

둥

(8)

路

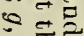

요

ก.

๑ 을

चृ

号芒

ㅇ. 뭉

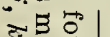

닌

요유

ஓ $\overline{0}$

골용

응 룰

류

등

要

5

등?

की 5

की

20

퉁

¿ळ

$\pi$

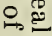

$\stackrel{2}{2}$

8

F

से

(6)

?

$\therefore$

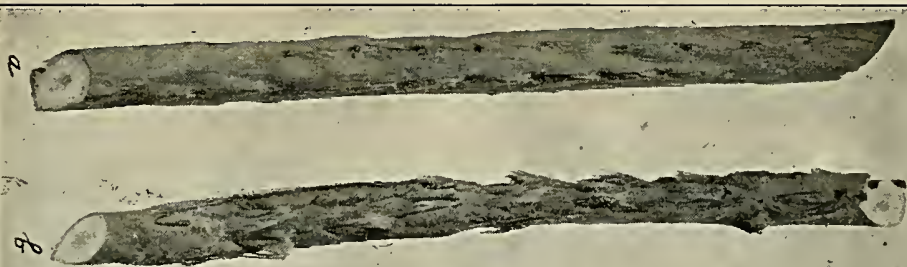

i 4 (1)

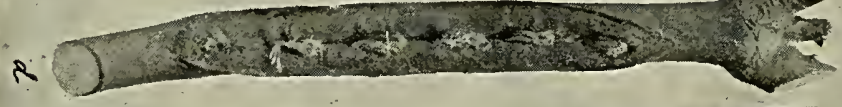

6

$\sqrt{5}$

$y^{2}=-130$

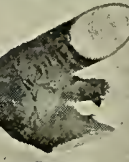

$\rightarrow \infty$

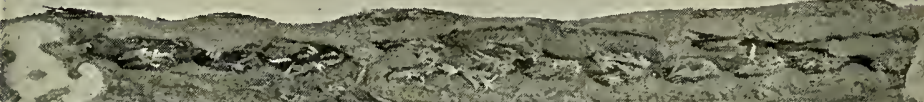

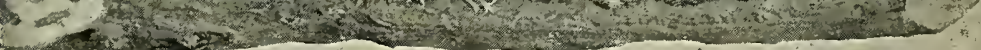

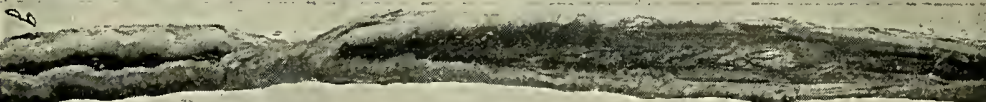



$\rightarrow$

t.

ex.

(1)

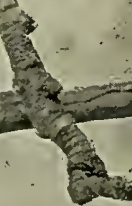

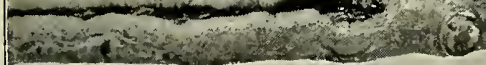

Q4.



늘

s

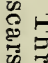

* 1 (

$x_{1}^{2}$

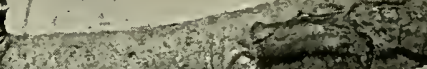

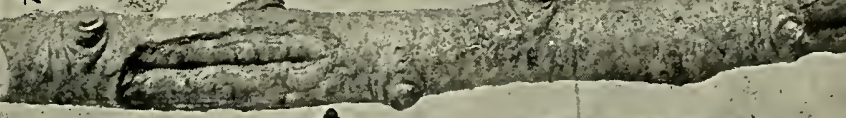

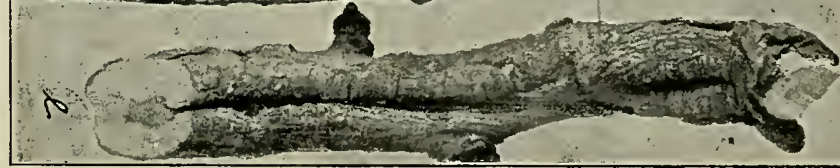

4 을

可

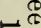

एव

贺 踝 



\section{CONTENTS.}

Introductory $\ldots \ldots \ldots \ldots \ldots \ldots \ldots \ldots \ldots \ldots \ldots$

Brief accounts of the Habits and Characteristics of the Insects.. . 262

A seventeen year and a thirteen year race, 265. Two distinct varieties of the adult, 265. Distribution and number of broods, 266 . Classification of the different broods, 266 . Enemies of the insect, 268. The English sparrow one of its worst enemies, 268. Injuries caused by the Cicada, 268 . Remedies and preventives, 269.

Broods recorded from West Virginia, Previous to $1897 \ldots \ldots \ldots 269$

Brood of 1880-1897, 269. Brood of 1881-1898, 270 . Brood of 1884-1901, 270. Brood of 1885-1902, 270 . Brood of 1889-1906, 271.

Broods in the State not recorded previous to $1897 \ldots \ldots \ldots \ldots$

Brood of 1883-1900, 272. The 1900 swarm, 272. Iuformation from correspondents, recording postoffices where the Cicada was observed or heard in 1900, 273. Brood of 18881905, 276. The 1905 swarm, 277. Brood of 1893-1910, 278. The 1910 swarm, 278.

Broods which probably extend into the state,.......... 280

Brood of 1882-1899, brood of 1894-1911, and brood of 1895$1912,280$.

Additional Information on Distribution of Broods, recorded from the state previous to $1897, \ldots \ldots \ldots \ldots \ldots \ldots \ldots \ldots \ldots \ldots \ldots$

The 1897 swarm, 281. Information from correspondents, recording postoffices where the Cicada was heard or observed, 281. Counties from which the periodical Cicada had been previously recorded, 281. Counties from which the Cicada had not been reported previous to $1897,283$. Review of information obtained from correspondents, 291. The Cicada probably does not occur above an elevation of 3,000 to 3,300 feet and where in the State, 294. Time of first general appearance, 294. Difference in time of appearance, 294. Influence of the weather on the appearance and development of the adults, 295. Valuable and interesting communication of $\mathrm{Mr}$. Luther Haymond, 296. Localities where the Cicada was reported as most abundant, 297 . Localities where it was more numerous than in former years, 298. Localities where it was not so numerous as formerly, 298. Places where a few were observed, 298. Places where but one example was seen or heard, 298. Places where the damage to fruit trees was reported as great, considerable or slight, 298. 
Review of Information obtained by the Author.......... 299

One example appeared two years ahead of regular swarm, 299. None seen or heard in the spring of 1896,299 . The song of the Cicada heard in September, 1896, 300. Night concerts, 300 . A visit to the border of the brood, 301. First appearance near Morgantown, 302. Secondary injury by the wooly aphis of the apple, 303. Cicada wounds seventeen years old, 304. Old Cicada wounds in sugar maple, 304. Treatment of old trees injured by the Cicada, 305 .

The 1898 Swarm.

Origin of the brood of the 17 -year race, 306 . Information from correspondents, recording postoffices where the Cicada was observed or heard in 1898,307 . The 1901 swarm, 314 . Special notice, 316. The 1902 swarm, 316. The 1906 swarm. 318.

Sections of the state where two or more broods overlap... . . 319

Hancock and Brooke counties, 319. Preston connty, 320.

Jefferson county, 320. Mineral county, 320. Grant and Hardy county, 320. Hampshire county, 320. Pendleton county, 320. Randolph county, 321. Pocahontas county, 321. Fayette connty, 321. Kanawha county, 321. Putnam county, 321. Mason county, 321. Jackson county, 322. Brooke, Ohio, Marshall, Tyler, Wood, Clay, Tucker aud Monongalia counties, 322. The state, 322 .

Summary .

How to avoid losses from Cicada injuries to fruit and other trees, 326 .

Special Information Desired Regarding the 1901 swarm....... 


\section{INTRODUCTORY.}

The edition of Bulletin 50 of this Station, entitled "The Periodical Cicada in West Virginia." issued January, 1893, was soon exhausted, only a very few copies being left at the close of the year of its publication. Therefore.in consideration of the fact that considerable additional data has been gathered with reference to the appearance of the insect in 1898 and 1900, and that it is due to appear in a destructive swarm over a large area in the southern part of the State in 1901. it seems that another Bulletin on the subject is desirable and important. We trust it will serve its main object of giving general information on this interesting and often destructive insect, and of warning farmers and fruit growers of the danger of serious loss of trees planted this fall or next spring within the area occupied by the brood which is due to appear next May and June. 



\section{THE PERIODICAL CICADA IN WEST VIRGINIA.}

By A. D. Hopkins. Ph. D.

There is probably no insect that has attracted more general interest and attention in this conntry than has the periodical Cicada, or the so-called seventeen-year locust. The earliest settlers doubtless associated its vast noisy swarms with the devastating invasions of the migratory locust of the East. Hence, the popular name locust which has been used so long that it is cloubtful if it will ever be entirely cliscarded for the proper name periodical Cicada. Its appearance at long intervals was the cause of much wonder and alarm among the early settlers, and many superstitions and erroneous beliefs prevailerl with reference to its habits and mission, until within the last half century, when something definite began to be learned with refererree to its true habits, life history, and distribution.

Since the species was first described by Linnaeus in 1758 , it has been the subject of special study by the leading entomologists of the country. The principal results of which may be found in Harris' Insects Injurious to Vegetation. 1852; Fitch's 1st Report on the Insects of N. Y., 1856: Riley's 1st Report on the Insects of Mo., 1868. Bulletin 8 of the Division of Ent., U. S. Dept. of Agr., May, 1885; and the annual Report of the U. S. Dept. of Agr., for 1885. Considerable additional information has been published from time to time by different State and Station entomologists and by the Division of Entomology of the U. S. Dept. of Agriculture. Bulletin 14 of this Division contains a general review of the subject up to 1898, together with much additional information, and a list of all of the principal publications on the subject from 1669 to 1898 . This is a most valuable and interesting contribution which should be consulted by every one who desires further detailed information on this insect in the United States. 


\section{BRIEF ACCOUNTS OF THE HABITS AND CHARAC- TERISTS OF THE CICADA.}

The adults or winged forms of the periodical Cicada appears in West Virginia during the later half of May and first half of June, varying with the altitude and latitude. About four or five days after the first appearance the males begin to sing. In about eight or ten days more the sexes begin to mate and in about four or five days more the females commence to deposit eggs. Each female is said to deposit three to five hundred eggs in numerous ragged punctures made by her powerful ovipositor in the twigs of shrubs and trees, and sometimes in the stems of herbaceous plant. These hatch in about six to eight weeks from the time they are deposited, and the young Cicada larvae emerge from the twigs and fall to the ground. They then burrow beneath the surface and enter upon their long and menial existence in

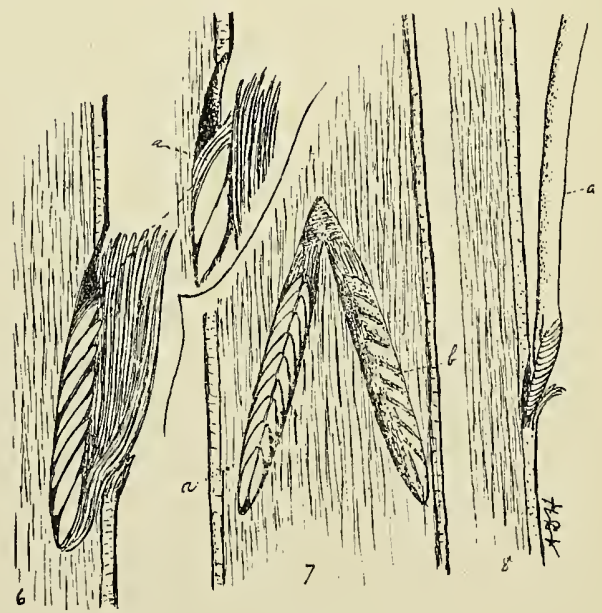

FIG. 1.

EGG CAVITIES SHOWING ARRANGEMENT OF EGGS.

6-Side view; $a$, showing how the entrance to the cavity is closed with wood fibers. 7-Pair of cavities with fiber covering removed showing arrangement of eggs in double row at $a$, and empty cavity showing partitions between eggs at $b$. 8-Showing. position of ovipositor (Fig. 2) in process of excavating cavity. 
the ground, feeding on the liquids of roots and possibly subsisting on such nutriment as can be obtained from the soil itself. They change their position from time to time and may rarely enter the earth for a distance of eight or ten feet, or more. By the 12th or 13th year the larva attains its full growth and in time changes to the intermediate or pupa stage. (See Frontispiece a-d.) During the spring of the fifteenth and sixteenth years, great numbers of the pupa, as was observed near the Experiment Station in April, 1895, and 1896 may be found near the surface, and a few individuals may emerge during May and


FIG. 2.

OVIPOSITOR OF FEMALE CICADA.

9 , ovipositor from side. a, lower or ventral part of tip which comes in contact with the wood. 10, ovipositor from below, with outer parts separated to show position of inner lancet, $b$, thlough which the eggs pass and are placed by it in position. 11, lancet tip of ovipositor from below; showing special arrangement of point and edges for gouging out the cavity; aa, outer pair of lancets. 12, ovipositor from above; $a a$, outer parts which together form a sheath for the inner lancet tube showing corrugated trough-like groove through which the eggs pass to tip. 13, lancet tip of ovipositor from above, showing special arrangement for adjusting the wood fibers and forming the egg cavity; $a a$, outer pair of lancets; $b b$, inner lancet.

Figs. 9, 10, 12 are enlarged a little more than 6 times; 11 and 13 are enlarged about 33 times. 
June of the sixteenth year and change to the winged or adult forms. Early in April of the 17th year, the pupae commence to make preparations to emerge from the ground by excavating burrows or exit galleries to the surface. These exits are completed by the last week in April. Ordinarily they only extend to the surface and are kept open from a depth of a few inches to a foot or more, but in some soils these exit holes are extended four or five inches above the surface by means of clay carried up from the subsoil. The pupae come from the ground in the evening and at night. usually between sundown and ten o'clock. and proceed to the nearest upright object, which may be a tree. the side of a building. fence. post or weed stem. anything in fact, upon which they can climb and expose their bodies to the action of the open air. In about an hour after emerging the

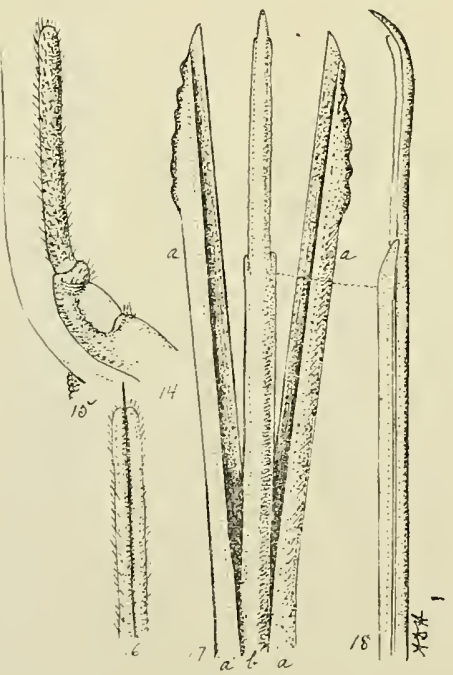

FIG. 3.

MOUTHPARTS OF ADULT CICADA.

14, beak or proboscis (labium) from side 15, piercing and sucking part (mandibular seta) which fits in a groove in the front of the proboscis as shown in 16, enlarged $3 \frac{1}{3}$ times. 17 , tip of piercers from above, enlarged about 66 times, to show form of lancets, a $a$, which together serve as a sheath for inner part $b$. $18, b$ from side. 
skin on the back splits open and the adult insect works its way out. The wings which are short and soft at first, rapidly clevelop, the body, wings and legs harden, and by the following day it is ready to take its flight and enter upon its short aerial life, which is limited to about thirty days. During this short period of its existence. in its winged or adult stage. it feeds but little if at all. the males devoting their time during the day to flying about and making a noise. while the roiceless females busy themselves depositing eggs.

A SEVENTEeN YEAR AND A THIRTEex year RACE.

In the southern or warmer sections of the United States. the swarms of the insect appear at regular periods of thirteen years. while in northern or colder sections. they appear every seventeen years. Thus the former are referred to as belonging to a thirteen while those of the latter belong to a serenteen year race.

TWO DISTINCT VARIETIES OF THE ADULT.

Two distinct forms or varieties of the insect occur in all swarms of both the thirteenth year and seventeenth year races, which are easily distinguished by the difference in size. and in

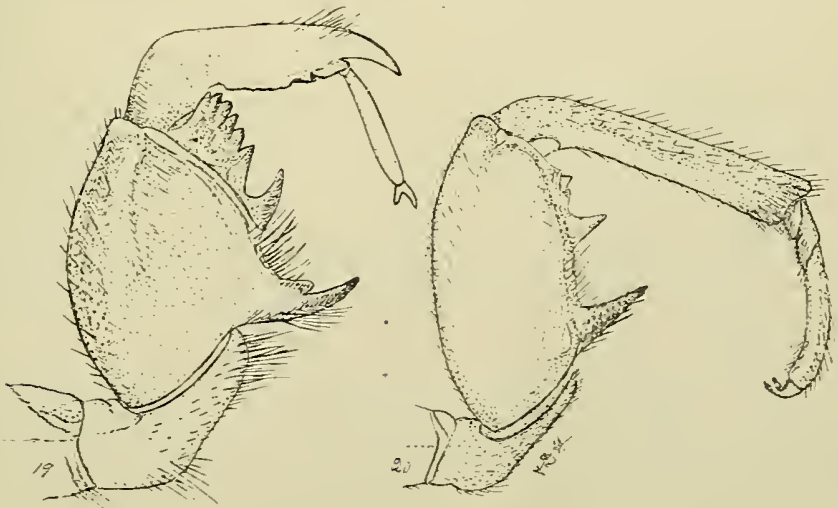

FIG. 4.

FRONT LEGS OF CICADA.

19, front legs of pupa; 20, front leg of adult female, enlarged $3 \frac{1}{3}$ times. 
the sound produced by the males. The large variety (Frontispicee $e$ and $f$ ) which is the typical form of the species is always more abundant and produces the familiar f-a-r-r-o sound, while the other is much smaller and its note is more shrill and quite different from that of its larger brother.

\section{DISTRIBUTION AND NUMBER OF BROODS.}

The species appear to be confined in its natural distribution to the United States, and to occur in all of the States east of the Rocky Mountains, except Maine, New Hampshire and Vermont. Within the area occupied by it there is, according to Marlatt ${ }^{1}$ about 30 more or less distinct broods of which 17 belong to the 17 year race and 13 to the thirteen year race. There is such a diversity in the areas oceupied by each brood and the years in which swarms of the different broods occur. that the insect appears somewhere in the United States every year.

\section{CLASSIFICATION OF THE DIFFFRENT BROODS.}

The earliest writers who attempted to classify the broods of this insect ${ }^{2}$ designated the recognized broods by the years of their appearance. .Dr. Asa Fitch, 1845-55, adopted a numbering system, which was changed by Walsh and Riley in 1868 to a different set of numbers expressed in Roman figures. In 1869 Riley adopted still another set of numbers to designate the 21 broods recognized at that time. This system prevailed until. 1898 when Marlatt proposed still another change in the numbers. Commencing with 1893 the 17 broods of the seventeen year race are numbered consecutively to 1909 , and then the 13 broods of the thirteen year race follow with XVIII for 1893 to XXX for 1905 .

The following table taken from Bull. 18 (previonsly cited) will make it clear how the numbers of the different authors correspond with the years in which the several broods appear and is invaluable for reference when different authors are consulted. 


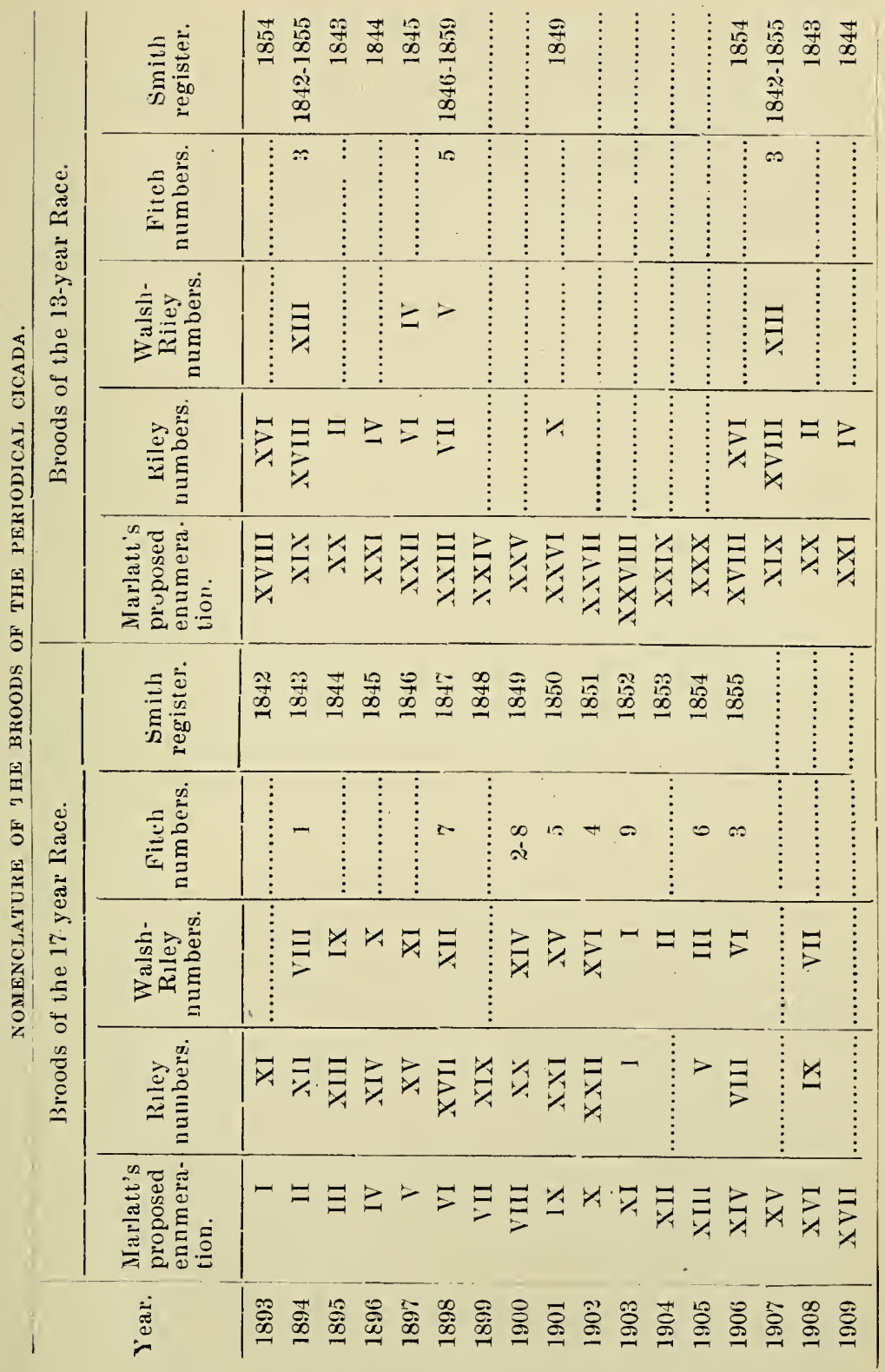


Since we have in West Virginia only the seventeen year race, the broods will be referred to in this bulletin by the years noted in the table, or years of last and next appearance. This is possible where but one race is under discussion.

\section{ENEMIES OF THE INSECT.}

The insect has numerous enemies which attack it during all stages of its existence, but more especially during that of the fully developed young and adult. Before it leaves the ground. it is devoured by hogs and other animals, and killed by disease. From the time they leave the ground until their mission as adults is ended, they are almost continually assailed, night and day, by parasitic and predaceous insects and other animal life; also by a fungus disease which in damp or rainy weather often takes the character of an epidemic, and kills them by the thousands.

THE ENGLISH SPARROW ONE OF ITS WORST ENEMIES.

During recent occurrences of the broods in the Eastern States it was observed by entomologists that the English sparrow was exterminating the cicada in and near the large cities and towns. Hence, we have at least one redeeming trait of this much abused bird.

\section{INJURIES CAUSED BY THE CICADA.}

The piercing of the roots of trees and other plants by the young of this insect, for the purpose of obtaining the sap as food, may do some harm, but it is believed that the injruy thus caused is rarely perceptible. The adult females, however, are capable of causing serious injury to young fruit trees in orchards and nurseries by the numerous punctures in the twigs, limbs. and main stems made by them in the act of ovipositing. (See Pl. $\mathrm{I}, a$ to $f$.) In fact, young orchards are often ruined and the aggregate loss thus occasioned to fruit growers and nurserymen reaches many thousands of dollars each "locust year." The injuries to the small branches of old trees is often very serious. Indeed, far more injury is done to such trees than is generally supposed and is an element of loss heretofore overlooked. (See Pl. I, $g$ to $l$.) 
REMEDIES AND PREVENTIVES.

It appears that no practical method of destroying the insect has been discovered, but with a knowledge of the years in which swarms or broods of insect will appear in a given locality, the losses from their attacks on young orchards can be reduced to a minimum simply by not planting young trees or shrubs during the two years previous to, or the spring of, the one in which the locust is to appear. Therefore a knowledge of the number of broods, the years in which they will appear, and the exact area covered by each in a given State or county, is of prime importance.

\section{BROODS RECORDED FROM WEST VIRGINIA PRE- VIOUS TO 1897.}

Up to the year 1897 , five broods of the seventeen year race had been recorcled from West Virginia, in the publications previously referred to, but very little had been published with reference to the areas occupied by each, except the one which appeared in 1885 in the Eastern Panhandle.

These published records of the broods may be briefly summarized as follows, expressed in years of their last and next appearance.

\section{BROOD OF I880-I 897 .}

This brood might be properly referred to as the West Virginia brood, since it was first recorded from Lewis county, Virginia, now West Virginia, in 1795. It also occupies by far a larger area of the State than cloes any of the other broods.

It also extends into Ohio, the southwestern corner of Pemnsylvania, and probably into Virginia from Hardy and Pocahontas counties. The records show that this brood has appeared in the State at regular intervals of seventeen years since it was first recorded in 1795, (see letter from Mr. Haymond on page 296,) and that up to 1897 it had been recorded from thirteen counties in West Virginia, viz: Barbour, Calhoun, Kanawha, Grant, Hardy, Harrison, Lewis, Marion, Monongalia, Ohio, Preston, 
Roane and Tucker. See subsequent records under the 1897 swarm.

$$
\text { BROOD OF 1881-1898. }
$$

The earliest record of this brood was from Wheeling, Va., (now West Virginia, ) in $1830,{ }^{1}$ and was subsequently reported from the same place in 1847 and 1864 ; also from northeastern Ohio, western Pennsylvania, New York, New Jersey, Wisconsin and North Carolina. There appears to be no record of its reappearance at Wheeling in 1881, and Prof. Webster ${ }^{2}$ states that it has not been reported from Ohio since 1864. Recent writers agree that this is a small brood, apparently dying out, especially in the southern range of its distribution. See subsequent records under the 1898 swarm.

\section{BROUD OF 1884-1901.}

This, like the brood of 1897 and 1898, was first recorded from the West Virginia area, it having been reported from Monroe county in 1833 and 1850 . It was subsequently reported as occurring in North Carolina, and Eastern Virginia. The swarms of this brood are reported as being much larger than those of the broods of 1898 and 1900, therefore it is quite important that the area occupied by it should be accurately determined. Up to 1897, it had only been recorded from Monroe and adjoining counties, but the indications are that it covers quite a large area in the State. See subsequent records under the 1901 swarm.

\section{BROOD OF 1885-1902.}

This brood, which was first recorded in 1715 , is said to be by far the largest brood of the seventeenth year race of the periodical Cicada. It is known to occur in eighteen States, and is divided into two sections, one occupying a belt extending from New York through the eastern portion of the Appalachian range, into northern Georgia and eastern Tennessee; the other covering nearly all of Indiana and about one-half of Ohio, and small areas in Kentucky, Illinois, Michigan and Wisconsin. 
This brood is distinguished especially in Pennsylvania, Maryland, and West Virginia, by the greater number of individuals in its periodic swarms, and is therefore liable to be the most destructive.

The area covered by this brood was quite accurately determined in 1885 by Dr. C. V. Riley, then chief of the Division of Entomology of the U. S. Department of Agriculture, and we find in his report published in the report of the U. S. Department of Agriculture for 1885, that the 1885 swarm occurred in "Berkeley, Grant, Hardy, Hampshire and adjoining counties. Jefferson and adjoining counties, Mineral and Morgan counties in West Virginia.",

\section{BROOD OF 1889-1906.}

This brood is of especial interest since it is evidently the one referred to over 250 years ago in Morton's Memorial as appearing in Plymouth, Mass., in 1633 or 1634 . This earliest published reference to the preiodical cicada was quoted by Harris ${ }^{1}$ and Riley ${ }^{2}$ as follows:

"There was a uumerous company of flies, which were like for bigness unto wasps or bumble bees, "which appeared in Plymouth in the spring of 1633.", "They came out of little holes in the ground * * * and made such a constant yelling noise as made the woods ring with them, and ready to deafen the hearers."

It was reported from Gallipolis in 1821 and from Kanawha, Va., (evidently Kanawha Valley) in $1855 .^{3}$

It is known to occur in West Virginia, Ohio, Kentucky, Virginia and several other States. It was recorded by Mr. E. A. Schwarz $^{4}$ as occurring near Harper's Ferry, Jefferson county, in 1889. In Bulletin 87 of the Ohio Experiment Station, issued in November, 1897, is found the following interesting reference to this brood in West Virginia in a copy of a letter from Mr. S. C. Larkin, of Rutland, Ohio, from which we quote the following:

* * "There is another locust district, lying south of ours"'(1897 swarm) "whose period comes eight years before ours, the line between

1 Harris Insects Injurious to Vegetation; Flint edition p. 207. 2 Bull. 8, Div. of Ent., U. S. Dep't. Ag'r. 3 Fitch's 1st report of insects of New York. 4 Pro. Ent. Soc., Wash., 1889. 
the two districts crosses the Ohio River from West Virignia near the mouth of Old Town creek in Ohio, then to Racine, cutting off all of the township of Letart. From Racine it passes to West Virginia and back again to Ohio at the mouth of Silver Run, just at the upper edge of Gallia county. * * * At Letrat, Ohio, where they were expected in profuse numbers in 1889 , there were very few."

Prof. Webster, the author of the Bulletin, states (p. 42) that:

"I found Mr. Larkin's statement to be substantially correct, as applied to brood XV. (189i) The line of separation seems to cross the river near Chester, in Gallia county, Ohio.' See subsequent record under the 1906 swarm.

\section{BROODS IN THE STATE NOT RECORDED PREVIOUS TO 1897. \\ BROOD OF 1883-1900.}

This brood has been known to occur in northern and western New York, eastern Ohio, and western Pennsylvania since 1832 and 1849, but had not been recorded from West Virginia. This is referred to as a small brood which does not attract much attention, except in a few comparatively small areas.

THE 1900 SWARM.

In 1897 Mr. L. S. Bambrick, of New Cumberland, Hancock county, stated, in reply to my inquiry, that the locust occurred in that locailty in 1883 .

On June 4th, 1900, the following request was sent out to numerous correspondents in the counties where it was thought the cicada might probably appear.

"Will you kindly inform us, on the accompanying return card, whether or not you have seen or heard of the seventeen year locust, (Periodical Cicada) in the vicinity of your home or postoffice, in your county or adjoining comnties in West Virginia, Penusylvania or Ohio. Any facts you can give will be greatly appreciated, and will aid is in our efforts to reuder the best service to the fruit interests of our state."

The replies to this request are given below, from which it will be seen that the distribution of this brood in the Northern Panhandle of the State is quite clearly defined.

It will be seen, also, from the reports of corresponclents, that while this brood occupies a small, well defined area, the swarm 
contained great numbers of individuals. Therefore, as compared with previous records of the small size of the brood and that it did not attract much attention in 1883, it would appear that it is not dying out.

In Bulletin 14, New Series, U. S. Department of Agriculture, Division of Entomology, the brood is recorded from Marshall and Ohio counties, and not from Brooke and Hancock counties, which with one exception in Ohio county, the following records reverse :

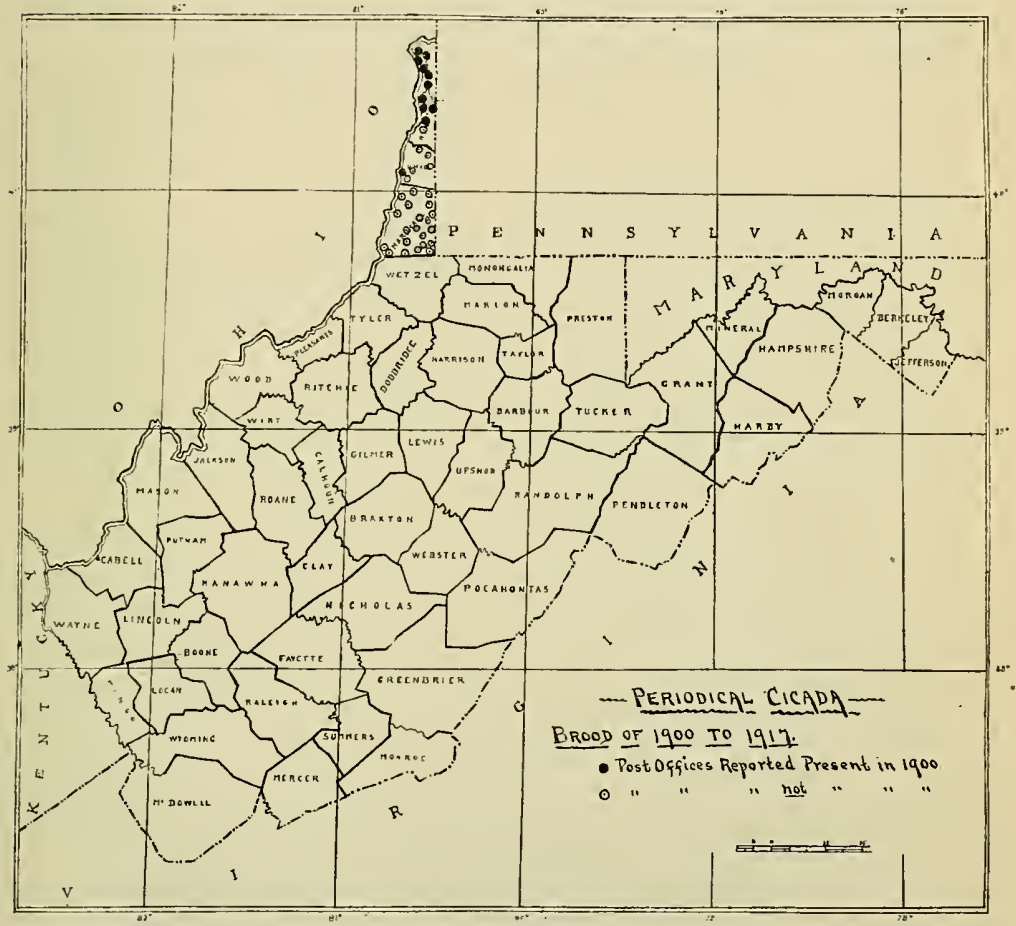

INFORMATI'N FROY CORREAPNNDENTS, RECORDING POSTOFFICES, WHERE THE CICADA WAS OBSERVED OR HEARD IN 1900.

Hancock:

Arruyo-R.H. Brown, June 9: * * * "they are here in quantity. More so than I have ever seen them. Apple orchards here canuot in my judgment escape great injury." L. F. Mahan, June 7th: "The seventeen year locust is out in force within a radius of 
5 miles. They exteud to Jefferson county, Ohio, just across the river from this office."

Fairview-G. W. Beaumont, June 9th: * * * "they are numerous in all this part of the county. I have killed several hundred in my orchard and there is still plenty yet." Dales Jackson, June 8: * * * "there are immense numbers of locust in all this vicinity, especially along the Ohio river. As yet I don't see that they have done any harm or stung any." G. W. Minesinger, June 14: * * * “they are very numerous in this vicinity and are in Ohio and Pennslvania, too." J. A. Huston, June $30: \quad * \quad * \quad$ "they made their appearance here about June 1 st and have been quite plenty until about three or four days back; they have been thimuing out and are now about gone." E. Sangfitt, June 9: * * * "the locust is here by legious and legions and still they appear to come." D. E. Mahew, June 5: "There are plenty of locust more thau I ever saw before." Robt. W. Pugh, June 6: "There are millions of locusts in the neighborhood of this postoffice."

Holliday's Cove-T. S. Chapman, June 9: * * * "the seventeen year locust have put in their appearance in localities where they missed three years ago. They are more confined to the lowlands this year. They are plenty in $\frac{1}{4}$ mile from our house and can hardly find one here while it was just the reverse three years ago." W. M. Lee, June 9: "The 17 year locust made its appearance the last days of May. Scarcely any in the valleys aud not very numerous on the adjacent hills. I learn that there are plenty east of us and in the north-west part of Washington county, Pa. At no time in the past thirty-two years has there been any locust to amount to anything in our valley, while within a half a mile on the hills they were very numerous. I presume that the domestic fowls have destroyed them, the valley being thickly settled and a great many fowls are kept. It is claimed by some that the sparrows destroy a great many of them, if so there is some good in the little fellows." J. A. Purdy, June 5; "The locust is here in great numbers. Saw them first on May 31'.' Geo. Owings, June 5: "There is no end of the 17 year locust about here, in fact you can't hear anything else and on all sides so far as I can hear." D. W. Hale, June 14: "The locust are here in large numbers and they seem to be all over this part of the county and not confined to any particular locality. It has just been 17 years since we had them in large uumbers."

Moscow-Frank S. Evans, June 6: "The Periodical Cicada is to be heard on every hand, are flying in all directions, have been here for a week."

New Cumbreland-L. S. Bambrick, June 7: “The locust are here in great numbers, They made their appearance the last days of 
May and increased rapidly first four or five days of June. They are also in the adjoining counties of Ohio and $\mathrm{Pa}$ - Columbian and Beaver- but $I$ understand not in Brooke Co., W. Va., as they were there two years ago." J. Paul Jones, June $千$ : "The locust arrived in great numbers about June 3 , thence in county generally. I inquired of a man from Culumbia Co., Ohio. Said there were but few. I .was in Washintgon county, at Burgetstown ou the fifth of month; did not see or hear any.'

Penrith- W. R. Wylie, June 8: “* * * the seventeen year locust (Periodical Cicada) have appeared here in Hancock Co., in large numbers. Also in adjoining counties-Washington and Beaver counties, Penn., and in Jefferson Co., Ohio. They were due here last year but only a chance one was seen at that time." Sallie Sanford, Asst. P. M. June 6: “ * * * the seventeen year locust has been heard at this place. They are quite numerous.',

Brooke:

Collier-W. S. Owings, June 5: "I have within the last 8 days seen a great many seventeen year locust on space of one sq. mile or less, on a cleared field, with a lot of under sprouts or bush, facing northwest; just came after rain in Brooke county. Cross Creek Township, W. Va., H. R. Standsbury, P. M. June 6: "The locust are here in limited numbers only as yet. Have not seen any but have heard them for several days." G. L. Hunter, June 8: "The seventeen year locust is here and they are very numerous. I saw them first the first of last week. I can't see that they have done much damage yet." S. V. Scott, June 7: " * * * there are lots of the seventeen year locust on our place. We can hear them singing all day in the orchard and woods."

Edington-J. K. Miller, P. M. June 6: "I heard the old familiar note yesterday while I was taking lunch in the cornfield."

Wellsburg-F. I. Morton, June 6: “* * * I have seen but an occasional locust but in the last few days have noticed the dried shells by the thousands; did not notice auy until a week ago. Since then saw a few shells on an apple tree-looked more closely today and find some trees fairly covered; the trunks or more particularly the inner branches often see three on one small leaf, besides thousands on the ground; also noticed under the tree, ground full of holes seemingly fresh. They had come up in the last three or four days. Have not heard of them anywhere else. J. C. Brady, June 7: * * * * "I plowed lots of them up but have not heard many yet." N. C. Hunter, June 11: I have heard the seventeen year locusts in two or three [localities in this county and in the lower edge of Hancock county, but have seen none. I do not think there are many as yet." Paul R. Strain, June 8: "I can say from personal knowledge that the Cicada, or locust, is thickly present in the 
immediate vicinity of my home and from common report judge that they are distributed equally numerous in territroy lying around Colliers and extending south to Wellsburg, in fact the northern end of. Brooke county is said to be occupied pretty thoroughly by them." Jon. D. Sanders, June 7: "The forests are humming with the insects at this time. Just in the edge of Washington Co., more abundantly than ever known before. While they were with us in ' 97 the Engilsh Sparrow redeemed himself of his many faults to a great extent by laying aside all other business to look after the Cicada. Nothing left but his thin transparent wings to mark the presence of a fierce conflict. 'Twas very gratifiyng to know that some little good was in him after being looked npon so long as a curse." S. C. Gist, June 8: "On a farm two miles from here in Brooke county a few locust were seen and two were heard to-day on the same farm." E. C. Carter, June $26: \quad * \quad * \quad$ "the 17 year locust have been very plentiful in our immediate neighborhood. But from what I can learn it was not the case in all parts of the county."

Ohio:

Wheeling-W. P. Wayman, June 4: "I heard them on the 4th." POSTUFFICES WHERE THE CICADA WAS NOT SEEN OR HEARD IN 1900 Brooke county, Wellsburg.

Marshall ", Board Tree, Bellton, Balls, Calis, Cameron, Dallas, Ella, Easton, Lime Stone, Loudensville, McMechen, Moundsville, Meighen, Pleasant Valley, Rocklick, St. Joseph, Sherrard, Wells, Wolfrun, Welcome.

Ohio " Elm Grove, Valley Grove, Potomac, West Liberty, Wheeling.

\section{BROOD OF 1888-1905.}

This brood had not, to my knowledge, been previously reported as occurring anywhere east of Indiana, but it would appear from information obtained from the most reliable source, that a brood corresponding to this in time of appearance, occurs in Putnam county. Mr. M. V. Brown, who lives near Buffalo, Putnam county, wrote: "We had a locust scourge here in 1854, 1871 and 1888." Later Mr. Brown writes in reply to my request for further information, as follows:

$$
\text { Buffalo, W. Va., Jan 19th, } 1898 .
$$

Dr. A. D. Hopkins, Morgantown, W. Va.

Dear Sir:-Yours of Jau. 14 to hand and contents carefully noted. I have no record, but remember distinctly that we had a bad locust year in this vicinity (opposite Buffalo) in 1888. I was building a barn 
that year and remember positively that locusts were numerous. * * I know I am not mistaken. We had locusts here in 1854 , in 1888 , $^{\circ}$ and I confidently expect them again in $1905 . * *$ We have had locust years between the the dates above mentioned; but the dates mentioned were the bad years, and I am satisfied that this is the 17 year brood. * *

Yours truly,

M. T. Brown.

I have since talked with other persons living in the same county, and they are all quite positive that the locust was very abundant in that locality in 1888 .

Mr. J. M. Healer, writing from near Snowden. in the adjoining county, Lincoln, states that he thinks the locust occurred there in 1888, and that they are due again in 1905.

\section{THE 1905 \&}

From the above information it would appear that a swarm may be expected in Putnam county and possibly in Lincoln

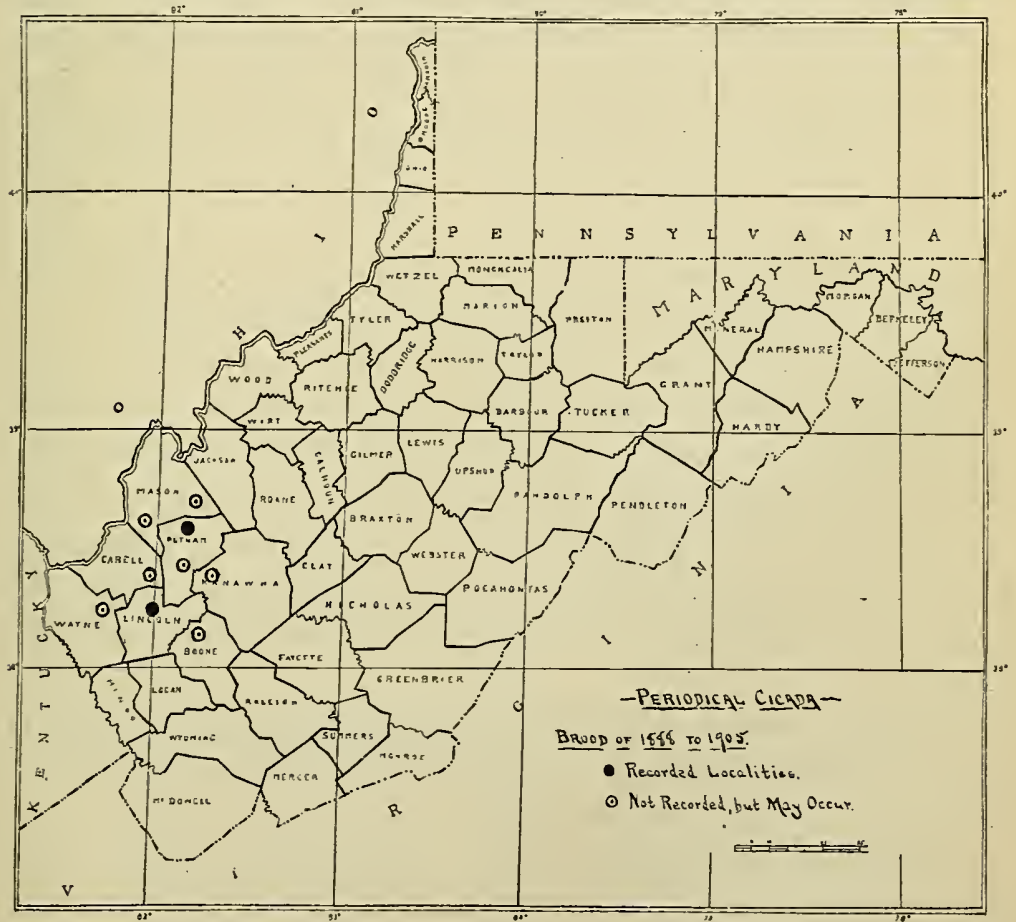


county in 1905, and since there are no previous published records with reference to the occurrence of this brood in the State, it is very important that our readers in that or any other section of the State should report to the Station the appearance of the Cicada in May and June, 1905.

\section{BROOD OF 1893-1910.}

This brood which was first recorded from the valley of Virginia in 1808, extends from North Carolina through Virginia into Maryland. It has also been recorded from Indiana, Illinois, Kansas, Kentucky and Tennessee, but no published records are found of its occurrence in West Virginia. That it does occur in this State, however, the following quotations from correspondents will show:

\section{THE 1910 SWARM.}

The information received from correspondents in 1897, indicate that a swarm of this brood appeared in 1893 over the greater part of Pendleton, the southern part of Grant and Hardy, and in a small section in Randolph county; also possibly in Jefferson.

Mr. J. G. Hammon, writing from Petersburg, Grant county, June 5, 1897, gives the following important information:

"The seventeen-year locusts are here by millions; were here seventeen years ago, also thirty-four years ago. They extend about four miles south, and there they come to the line where the locusts were four years ago. This line extends as far east and west as I am acquainted with the county. I remember when I first knew anything about the locust was in 1842 ; the next time in 1859, then in 1876 and 1893, and always four years later.

In another letter in reply to my request for further information with reference to the dividing line between the 1893 and 1897 swarms, Mr. Hammon says:

"The line that divides the area of the cicada, as stated in my other letter, commences on the western part of Grant County and near the Pendleton line, about four miles south of Hope- 
ville P. O., and then about one mile north of Pansy P. O., and a short distance south of Masonville P. O., with a straight line through Hardy County and entirely to the Virginia State line; from there I am not acquainted with the line, but I have traveled this county and Hardy, and know my statement to be correct."

Mr. W. L. Kellerman, of Kellerman, Grant county, states on card dated June 22d, 1897 :

"The locust did not occur here this year, it occurred here in 1894." [1893 ?]

Mr. S. E. Hinkle, of Seemly, Grant County, says: "The seventeen-year locust is not in the vicinity of this office, but is about three miles northeast from here. They were here four years ago (1893.)

Correspondents from the following postoffices in Pendleton county state that the locusts occurred in 1893: Sugar Grove, Sweedlen Hill, Shreves, Brushy Run and Oak Flat.

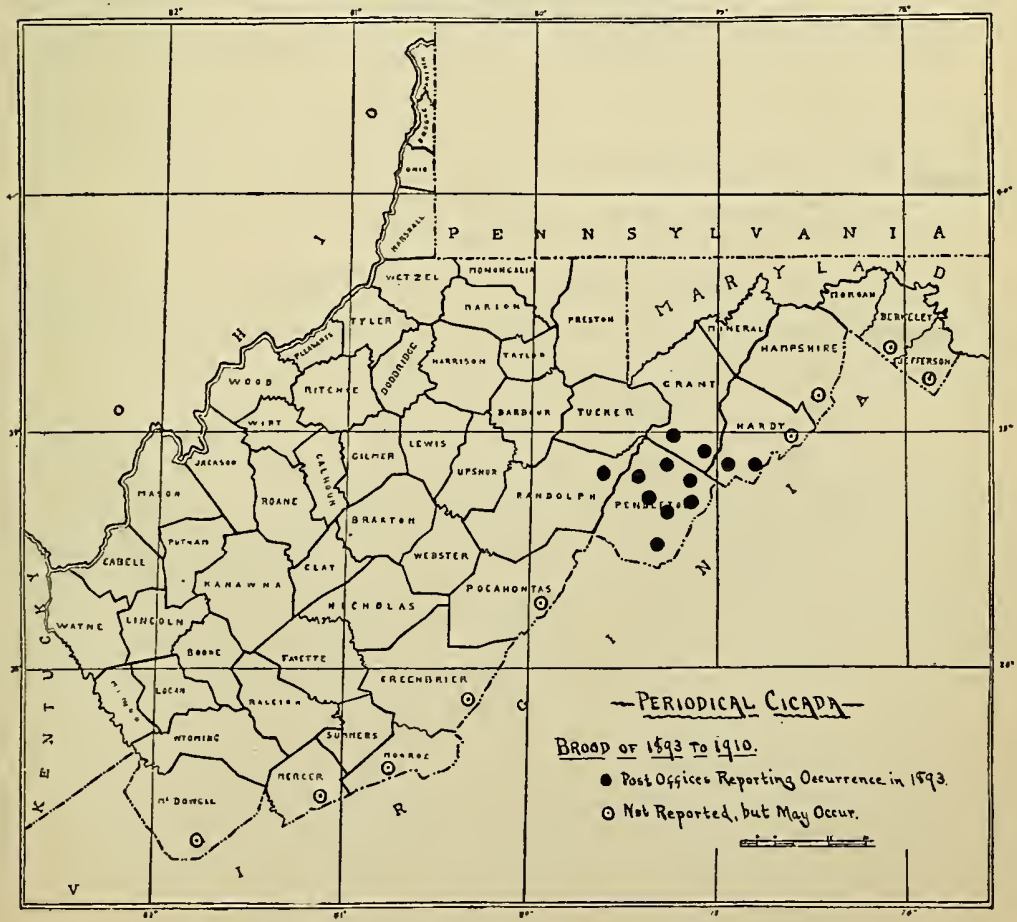


J. C. Harper, postmaster at.Day's Mills, Randolph county, states on card dated June 19th, 1897: "The seventeen year locust was in our vicinity in 1893, none here this year. I have seen four locust years." If he refers to this brood the years would be 1842, 1859, 1876, 1893.

This locality is of special interest, since it is probably another example of a small detached section which has established itself on the opposite side of the main ridge of the Allegheny Mountains. Day's Mills is at an elevation of 2,500 feet in a narrow valley surrounded by high mountains 3,000 to 4,000 feet altitude and it seems quite remarkable that the insect should find its way in there and establish a colony.

\section{BROODS WHICH PROBABLY EXTEND INTO THE STATE.}

BRnOD OF 1882-1899.

From the records of the U. S. Division of Entomology, Bulletin 14, new series, it would appear that this brood should occur in the Northern Panhandle, since it is recorded from Allegheny and Washington counties, Pennsylvania.

BROOD OF 1894-1911.

This brood occupies a large part of Virginia, and extends through Maryland, Pennslyvania to Connecticut, and will probably extend into some of the eastern counties of our State.

$$
\text { BROOD of 1895-1912. }
$$

It is possible that representatives of this brood may occur in small numbers in some sections of the State. It should be looked for in Monongalia county, where a single example was observed in 1895. See under "Information obtained by author.", 
THE PERIODICAL CICADA IN WEST VIRGINIA.

ADDITONAL INFORMATION ON DISTRIBUTION OF BROODS RECORDED FROM THE STATE PREVIOUS TO 1897.

\section{THE 1897 SWARM.}

The appearance of the 1897 swarm, over a large part of the State, offered an excellent opportunity for the writer to obtain information with reference to the area occupied by this and other broods. Some four hundred reply postal cards were mailed on May 28,1897, to correspondetns and postmasters in all sections of the State, bearing the following request:

"Will you kindly inform us ou the accompanying card, whether or not the seventeen year locust appeared in the vicinity of your postoffice, this year? By so doing, you will enable us to render valuable services to the,fruit industry of the State."

Replies to this request were received from over three hundred postoffices, and when they were classified, it was found that every county in the State had been heard from; also that a large amount of valuable information had been gathered.

INFORMATION FROM CORRESPONDENTS, RECORD.

\section{ING POSTOFFICES, WHERE THE CICADA} WAS HEARD OR OBSERVED.

COUNTIES Fron WHICH THE PERIUDICAL CLCADA HAD BEEN PREVIOUSLY RECORDED.

Barbour county :

Burnsville, June 4; Mansfield, June 7; Meadowville, June 8; Nesterville, June 4; Peel Tree, June 7; Philippi, June 4.

Calhoun county:

Arnoldsburg, June 8; Grantsville, June 7: Appeared about the middle of May Mount Zion, June 5.

Grant county :

Pansy, June 18: About reaches this office but no further toward Pendleton; this is five miles from Pendleton line. Masonsville, June 19; Petersburg, June 5: "Were here 
17 and 34 years ago. They extend about four miles south to the line where they occurred in 1893. Remember the '93 brood in 1842, 1859, 1876 and 1893, and that they occurred four years later at Petersburg. Bismarks; Black Rock; Dorcas, June 24; Jordan Run, June 14; Sol. K. Nelson, P. M. "Extend to Pendleton county line; did not cross the line in 1880." Martin Greenland, June 17; Maysville, June 5: "Just coming out of the ground." Maysville June 11; Medley, June 5; "Three different times within the past 20 years. (1902 overlaps 1897.) Seymoursville, June 17.

Hardy county :

Inkerman, June 24; Old Fields, June 17: "In wood; none in Hampshire; occurred there in 1885.'" Baker, June 19: "Occurred here in 1885; very numerous (Overlap 1885-1897.) Fabins, June 18: "Occurred in 1885; very common; from record in the Bible." (Overlap 1885-1897). Moorefield, June $5 . "$ We had them in $1880,1884,1871$, also in 1863 . Mathias, June 18.",

Harrison county :

Bridgeport, June 6, June 15.

Kanawha county :

Handley June 7; Kendalia, June 21; Lewiston June 9 and 18; Shrewsbury, June 22 : "has been." Maldin, June 6; Island Branch, June 25: "Damage undoubtedly very great" (?). Chilton, June 23: "Near here." Caklin, June 18: "Appeared at least three weeks ago; numbers diminishing." Connelton, June 18, Coalburg, June 25; Belle, June 21 : "Disappearing fast on account of heavy rains." Apgah, June 21; Charleston, June 7: "Ovipositing. Occur on hills on opposite side of river; none in valleys." Farm, June 7: "None near this office, but heard of them in other localities." Fairfield, June 24: "Locusts are on this creek (Cobin) from Kanawha river up about four miles."

Lewis county :

Berlin, June 12; Weston, June 8: "Within two miles of Weston." 
Monongalia county :

Dunkard, Pa., (Residence, W. Va.) June 7 ; Green Co., Pa., (Residence, W. Va.) June 9; Dilliner, June 9; Pedlar, June 8: "Out about a week." White Day, June 9; Morgantown, June 9; Easton, June 9 ; Ice's Ferry, June 9.

Marion county :

Thoburn, June 7 : “Appeared first May 25; commenced singing June 1."

Ohio county :

Elm Grove, June 7: "Have been appearing for a week." 'Roney's Point, June 7: "Have been singing around for about a week." Wheeling (Wheeling Creek) June 5; Wheeling, June 12: "None in the Valleys, but abundant on highlands." Preston county :

Cranesville, June 16: “Appeared about June the 12"'Aurora, June 15: "Late coming on account of cold weather." Bruceton Mills, June 18: "Appeared the last week in May." Morgan's Glade, June 4 : “Appeared June 3” ; Rowlesburg, June 7 ; Brandonsville; Glade Farms.

Roane county :

Oakville, June 28; Peniel, (Marshall,) June 7 ; Ryan, June 5. Tucker county :

St. George, June 19; Red Creek, June 19; Parsons, June 19; Hannasville, June 18: "Appeared the first of June." Hendricks, June 18; Bretz, June 12; Lead Mine: “Four locust years observed, 1846, 1863, 1880, 1897." Age 63 years.

Pleasant Run, June 19; Texas, June 22.

COUNTIES FROM WHICH THE CICADA HAD NOT BEEN RECORDED PREVIOUS TO 1897.

Brooke county :

Fowlers, June 7 ; Wellsburg, June 5 and 7.

Braxton county :

Flat Woods, June 7.

Clay county:

Wattsville, June 11: A correspondent from Wattsville, Clay 
county, traveling through Braxton, found them in abundance. Clay, June 14; Big Otter, June 9.

\section{Doddridge county :}

Smithton, June 8; Market, June 8; Flint, July 19: "Not as common as in 1880.',

Fayette county :

Powellton, June 18; Montgomery, June 17 ; Gauley, June 17 ; Eagle, June 18: "Not much damage; rains have destroyed them." Deepwater, June 18: "Killing all of the fruit trees up here. Trees smothered to death with locusts." June 21 "Has been in this locality for the last month. Saw the locust at Nutalburg 14 or 15 years ago. 1883 or 1884 appearance similar to that of 1884 or 1885." Kanawha Falls, June 17: "Appeared about May 19. Made their appearance about the same date in 1880."

Gilmer county :

De Kalb, June 12: "Appeared between the 15 and 20 of May. Troy, June 10: "Doing considerable damage with all his noise." Alfred, June 9.

Hardy county :

Moorefield, June 5: "We had them in 1880, 1884 and 1871; also in 1863.",

Hancock county :

Holliday's Cove, June 5: "In great abundance in one orchard on the Chapman fruit farm; not heard of on any other farm." Congo, June 19: "Just a chance locust as yet." Jackson county :

Ravenswood, June 7; Kenna, June 8; Jackson, June 8: "More numerous here than any where I have been." Grasslick, June 8: "Thicker than they ever wึere in this section." Elk Fork, June 15; Cottageville, June 9 ; Angerona, June 9: "Commenced to sting the orchard. - Already stinging the trees."

Masrhall county :

Migher (Rosby's Rocks) June 9: "Not so numerous as on other locust years." Moundsville, June 11: "Great numbers 
a short distance north, east and south.', Glen Easton, June 17; Cameron.' June 9: Welcome, June 10: Wells, June 5: "Have seen three broods which have made their appearance at regular intervals of 17 years." Sherrard, June 16: "Were here for several weeks : did very little damage and soon disappeared."

Mason county :

Flat Rock, June 22: "Only on spots, some places plentiful." Sassafras, June 7: "Thicker than they were ever known by the oldest settlers." Pt. Pleasant, June 3 : "Not as numerous as in fomer years, about half a crop: they are making their mark on the apple trees." Rockcastle. June 7. Mineral county :

Barnum, June 17: "But one locust so far." Laurel Dale, June 18: Since the first inst. June 17; Elk Garden, June 19. Nicholas county :

Winston, June 19: "Stinging the limbs in sone sections." Snow Hill, June 20: "A few here: thick on Beaver, 35 miles from here." Ophelia. June 26: Leivacy: "A few here, a few miles from this place;' Fowler Knob, June 24: "Not in this immediate neighborhood, but are within one and a half miles north of this." Summersville, June 7 and 15; Craigsville, June 7: "Apparently more numerous than in 1880." Putnam county :

Buffalo, June 8, M. V. Brown: "In large numbers in certain localities. We had a locust scourge here in 1854, 1871, 1888." Extra, June 8: "By the thousands on the east side of the Kanawha, but none on the west side." McGill, June 10: "Doing great damage to young orchards. The limbs are falling down from being split." Poca, June 12: "None at this immediate vicinity."

Pendleton county:

South Mill Creek, June 19: "Some locusts here.",

Pocahontas county:

Edray, June 22: "Not as numerous as usual." Sunset, June 30: "Plentiful and have done considerable damage, 
killing small peach trees." Sunset, June 4; Greenbank, June 21; Frost, June 22; Huntersville, June 21, June 16: "The locust entered in this vicinity in a belt of about three miles, extending indefinitely northeast and southwest." Marlintgon, June 7.

Pleasants county :

Hebron, June 3: "Not so many as in 1863 and 1880." Calcutta, June 4; Eureka, June 6: "Mating but no signs of ovipositing." Grape Island, June 11, birds and chickens destroy many near dwellings." Josiah, June 4: "Seemed thicker than in 1880."

Randolph county :

Kingsville, June 23 ; Kerns, June 18; Mingo, June 21; Montrose, June 18; Roaring Creek, June 21; Star, June 21; Beverly, June 8; Elk Water, June 8; Elkins, June 7: "Came here about June first." Huttonsville, June 19; Helvetia, June 11: "In 1863 and 1880 numerous about 8 miles below; few here, more in 1880 than in 1863 . This year great many more than 1880. First appearance June 14. Below here came about June 1." Valley Bend, June 19; Womelsdorf, June 19. Ritchie county :

Hartley, June 9.

Summers county :

New Richmond, June 9.

Taylor county :

Flemington, Tapan, June 14; Thornton, June 12.

Tyler county :

McKin, June 7; Meadville, June 7: “Appeared May 24." Pusley, June 7: "Appeared May 24."

Upshur county :

Rural Dale, June 7: "Was here in '63 and '80. I think now more numerous than '80, but not as many as in '63.' Buckhannon; Frenchcreek; Hampton.

Wetzel county :

Archers, June 10: "Said to come up every 14 years," 
Marion, June 7: "Part just coming ont of ground." New Martisnville, June 8: "More numerous back from river." June 8: "Not so numerous as in former years." Paden Valley, June 7; Sincerity, June 12.

Webster county :

Burgo, June 24; Addison, June 22; Boggs, June 7; Lanesbottom; Mayton, June 7; Hackers Valley, June 19; Upper Glade, June 18: "Ovipositing (?)." Welch Glade, June 19; Removal, June 26.

Wood county :

New England, June 15; Vienna, June̊ 10: “Confined most exclusively to timber land"'; Eatons, June 7; Lockhart's Run, June 7; Mineral Wells, June 12; Washington, June 7; Athey, June 7.

Wirt county:

Lucile (Reedy Ripple,) June 3. "Have been very numerous, but now nearly gone." Limestone Hill, June 11.

POSTOFFICES WHERE THE CICADA DID NOT OCCUR IN 1897.

Boone county:

Madison, June 8; Bald Knob, June 10: “One Cicada observed June 1st." Coon's Mills, July 3.

Berkeley county :

Martinsburg (by personal inquiry.)

Fayette county:

Maywood, June 21; Hawks Nest, June 18; Cotton Hill, June 18; Raven's Eye; Sewell, June 11; Eayetteville, June: "Were in this locality nearly 17 years ago."

Greenbrier county :

Falling Springs, June 9; Lewisburg, June 8: "Saw one locust; I think they occurred here in 1884; am told that locnst year will be in 1899."

Grant county:

Hamilton, June 17; Ketterman, June 22; Mt. Storm, June

17: "Reported six miles due south on eastern slope of Allegheny Mountains. Never known here." Seemly, June 
21: "Is not in the vicinity of this place, but occurs about 3 miles northeast; were here in 1893." Wilson, June 17: Old settler says, "Never been seen in this locality, though abundant a few miles either side." Bayard, June 5, 17 : "Quite numerous a few miles east."

Hancock county :

New Cubmerland, June 8: "Locusts were here in 1883." Blanch, June 19; Penrith, June 17: "None here. Occur near Holliday's Cove.",

Hampshire county :

Glebe, June 19: "Will occur in 1902." Green Springs, June 17; Purgetsville, June 18: "No locusts here. Plenty 8 miles south. Also plenty about same distance east and west." Kirby, June 8: "Will occur in 1902. Here last 1885." Mutton Run, June 7: "Think they will appear in 1901 or '02." Spring Gap, June 9; Capon Springs, June 14 : "Has been 12 or 14 years since locust year here." Slanesville, June 7: "1902 will be our locust year." Romney, June 7: "Here 1885, will occur 1902."

Jefferson county :

Summit Point, June 7: "Occurred, I think, in 1885."

Kanawha county :

Lewiston, June 9: "Heard locust (one) $\frac{1}{2}$ mile below house on 16th inst." Winifred, June 18: "Occur about 5 miles distant along the river." Tornado, June 18; St. Albans, June 22 ; Rome, June 21.

Lincoln county :

Snowden, June 9: "If I remember right, here in 1888; will be due in about 1905." Hamlin, June 11 ; Griffinsville, June 11; Chapmansville, June 14.

Mercer county :

Siberia, June 16; Princeton, June 19; Athens, June - : "Locust year will be in 1900 ; last was in 1883." Corrected to 1901, in letter dated December 17. 
Mineral county:

Hartmansville, June 17: "Locusts numerous on east side of mountains about 3 miles distant, altitude 2,900. They occur about one half way down mountain." Headsville, June 23; Patterson's Depot, June 17; Piedmont, June 17; Alaska, June 4: "Remember them as far back as '46. I believe we had them in '63 and '80." Bealington, June 17; Keyser, June 14, 19 and 23: "Occurred here in 1885": "13 years since here."

Mingo county:

Nolan, June 7.

Mason county:

Brighton, June 19.

Morgan county:

Great Cacapon, June 4.

McDowell county :

Horsepen, June 14.

Monroe county :

Gap Mills, June; Peterstown, June 21: "Locusts will not appear until 1900." Rock Camp, June 8.

Nicholas county :

Nicholas, June 27; Eye, June 22: "17 year locusts only come within 1 mile of Eye; 3 miles northwest numerous." Pool, July 13: "Within 4 miles of this place."

Pendleton county :

Brandywine, June 21; Dry Run, July 9; Fort Seibert, June 21: "Occurred in 1893." Harper Mills, June 28; Kline, June 19: "Occur 10 miles north." Mouth of Seneca, June 18: "Occurred in 1893." Macksville, June 22; Oak Flat, June 23: "Occurred in 1893", South Mill Creek, June 19: "Few locusts"; Sugar Grove, June 21: "Occurred in 1893;" Sweedland Hill: "Occurred in 1893;" Shreves, June 23: "'Occurred in 1893;" Bushy Run, June 18: "Occurred in 1893. Occur 4 miles north at present." Franklin, June 8; Upper Tract, June 18. 
Pocahontas county :

Academy, June 21; Gillespie, June 21; Top of Allegheny, June 23; Travelers' Repose, June 21: "Rare in woods." Buckeye, June 21: "Will occur in 1901;" Dunmore, June 21: "No locusts within 8 or 10 miles of this place." Linwood, June 21.

Putnam county :

Pliny, June 8: "None here below the Kanawha River; was here about 9 years ago." South Side, June 8: "Heard a few; will occur about 10 years hence."

Raleigh county :

Clear Creek, June 19; Egeria, June 22 ; Raleigh C. H., June 18; Roxie, June 19: "Will occur in 1901;" Sunflower, June 17: 'I think will occur in 1901;' Prosperity, June 5: "Occur in 1901." Table Rock, June -; Red Bird, June 14. Randolph county :

Adolph, June 21; Alpena, June; Day's Mills, June 17: "Present 1893." Job, June 18: "Never has been any in the Canaan Valley, Tucker Co., to my knowledge"; Helvetia, June 19: "Were within a radius of 12 miles of the postoffice"; Harmon, June 22; Horton, June 30; Pickens, June 9: "None within a radius of 12 or 15 miles of this place." Cheat Bridge, June 2:.

Rockingham county ( $\mathrm{Va}$ ) :

Cherry Grove, June 19.

Summers county :

Lowell, June 21; Hinton, June 7; Green Sulphur Springs, June 7; Pipestem, June 18; Meadow Creek, June 17; Ellison, June 21; Clayton, June 21: “1884 was last locust year in this vicinity; 1901 will be locust year." Crump's Bottom, June 24.

Tucker county :

Thomas, June 18: "None within a radius of 8 or 10 miles." Wayne county :

Wayne, June 7: "Heard one singing yesterday (June 6.) 
This is not regular locust year with us." Echo, June 10:

"Heard only one sing. Saw none."

Wyoming county :

Oceana, June 12; Baileysville, June 14.

REVIEW OF INFORMATION OBTAINED FROM CORRESPONDENTS.*

The counties added to those recorded previous to 1897 are as follows: Brook, Braxton, Clay, Doddridge, Fayette, Gilmer, Hancock, Jackson, Marshall, Mason, Mineral, Nicholas, Pocahontas, Putnam, Pleasants, Ritchie, Randolph, Taylor, Tyler, Upshur, Wetzel, Wirt, Wood and Webster. Two correspondents from two postoffices in Wayne county reported that they heard the insect, but saw none. Similar statements came from correspondents in Summers, Boone and Greenbrier counties.

Negative reports were received from the fourteen remaining counties, in which the brood evidently does not occur to any noticeable extent, and also from seventeen counties which are only partially occupied by the brood. Thus, it is possible to show quite accurately on the accompanying map, the area occpuied by this brood in West Virginia. The fact that not a single negative report was received from the 124 correspondents within the area occupied by the brood, is evidence that the infested area indicated on the map was pretty thoroughly covered, especially in the wooded portions, although there may have been numerous small sections in which it did not occur in sufficient numbers to attract attention.

A most interesting feature was noticed by a number of correspondents on both sides of the border line of the brood, namely: That up to a certain well-defined limit, it was common to find the insects in enormous numbers, in fact, far more numerous than at any point farther back in the main body, while a few hundred yards in advance, scarcely a single example could be seen or heard. This well-defined limit would sometimes follow the bank of a river, small stream or mountain range, while again it would be found crossing at nearly right angles, broad rivers

*The following reference to the $1897 \mathrm{swarm}$ is taken from Bull. 50, with little change. 
and high mountain ranges. As for example, the Ohio River at the northern limit of the swarm, near Holliday's Cove, in Hancock county, at its southwestern limit in Mason county, the main Allegheny range at the head of the Elk and Valley Rivers and at the westren corner of Mineral county. Thus the limit of the range of the brood is quite distinctly marked as shown on the map reproduced here from Bull. 50, 1898.

Beginning at the mouth of the Great Kanawha it follows the northeast bank of this river to near the mouth of Pocatalico River, where it crosses the Kanawha and extends southeast a few miles back from the river, until it reaches about the Fayette county line where it takes a northeast course and again crosses the Kanawha near the mouth of the Gauley River, which it follows north and then east to the mouth of Hominy Creek; thence south, up the valley of this creek near the Greenbrier county line. From the valley of this creek to the head of the Valley River, the border line is not very well defined, but doubtless extends northeast along the northwestern slopes of the mountains, between 2,000 and 3,000 feet elevation, to Upper Glade in Webster county where it crosses over to the Elk waters, and follows the valley and main branch of this stream to near the Pocahontas and Randolph county lines it being recorded from Bungo P. O. in Webster county and Elkwater in Randolph county; then it evidently continues below the 3,000 foot contour across Buffalo Bull Mountain and the ridges between the streams flowing into the Elk River and the head water streams of the Little Kanawha, Buckhannon and Middle Fork Rivers, near Pickens, Star, and Adolph postoffices; thence along the western slopes of Rich Mountain until it finds a pass, through the 3,000 foot barrier, to the eastern slope which it follows northward to near the head of the Valley River at Mingo Flats. Here a barrier of 3,300 feet elevation is met with, oper which at some time, examples of this brood must have succeeded in passing, ${ }^{*}$ since we find a detached section of the brood forming a 

narrow belt about three miles wide extending from Edra (which is at or near 3,000 feet elevation) to Marlington, Huntersville, Sunset, Frost, and probably to Greenback, Pocahontas county, and may possibly cross the mountains and extend into Highland and Bath counties, Virginia.

From Mingo Flats the border line extends down the Valley River, or along the western slope of Cheat Mountains, into Tucker county, where it extends eastward into the valley of Cheat 'River, which it follows southward to the mouth of Red creek on Dry Fork at the southern border of the county: thence northward around the southern and western slopes of the Back Bone Mountains to near the Maryland line at Aurora in Preston county, then apparently almost due north, a short distance west of the Maryland line through Preston county to the northeast corner, where it crosses the State line into Pennsylvania.

Another curious feature is found in the eastern panhandle of the State, where a detached section of the brood occupies portions of Mineral, Grant and Hardy counties. Here the boundary lines are even more distinctly marked and accurately determined than those of the main body west of the mountains. It enters the western corner of Mineral county, between Barnum and Harrison on the north fork of the Potomac river, and extends east in what appears to be a narrow strip, through a gap in the main front range of the Allegheny mountains at a point where the northwestern turnpike crosses; thence, down the eastern slope of the mountains to New Creek Valley, near Laurel Dale, and up the valley into Grant county where it spreads out and covers the greater part of the county. The western border follows the eastern slope of Allegheny Front southward to near the Pendleton county line, which, according to the Postmaster S. K. Nelson, at Jordan's Run, it did not cross in 1880. From near the western corner of Grant county, the border line extends almost due east, across numerous narrow valleys and mountain ranges, through this and Hardy county to the Virginia line. Then it extends north and west to the Hampshire county line, 
which follows closely to the New Creek Valley, thence northward, over the mountain at the low-gap previously mentioned. This gap in the 3,000 foot barrier is about a mile wide and the elevation is 2.700 feet. This narrow strip doubtless extends into Maryland and possibly connects with a spur of the main body in Somerset county, Pennsylvania, through a gap in the Great Back Bone and Meadow Mountains.

THE CICADA PROBABLY DOES Not OCCCR ABOVE AN ELEVATION OF 3,000 TO 3,300 FEeT ANYWHERE IN THE sTATE.

The information gathered from correspondents and from personal observation, leads me to beliere that the periodical cicada is confined in its natural distribution in West Virginia to what is known as the upper austral and transition life zones, and that it will rarely occur in the Canadian zone which lies above an eleration of 3,000 feet.

\section{TIME OF FIRST GENERAL APPEARANCE.}

The time of first general appearance of the swarm varied considerably. Between the northern and southern border there was. as indicated by the records, a difference of nearly two weeks and between the lowest and the highest elevations within the area covered by this brood, there appears to have been a difference of nearly four weeks.

This variation appears to be due to the difference in climate between southern and northern sections and low and high elerations, which in the former, amounts to some 3.5 degrees, and in the latter to over 10 degrees in average summer temperature. The latter being equal to the difference in the climate or arerage temperature between Chattanooga, Tenn., and Cleveland, $\mathrm{O}$.

\section{DIFFEREYCE IN TJME OF APPEARANCE.}

From evidence gathered by the author during the spring and summer of 1897 , it would appear that there is about $3 \frac{1}{2}$ days difference in the time of the first general appearance of the cicada for each degree of difference in the average or mean summer (April to September inclusive) temperature between any 
two points in the State, whether it be due to difference in latitude or altitude.

Thus if, as was indicated by reports, the swarm commenced to appear near Point Pleasant between the 12th and 14th of May. they should have appeared on the hills near Morgantown between May 22d and 24th, and at the eastern border of Preston county at an elevation of 2,700 feet June 12 th to 14 th. My records show that the first general appearance of the swarm near Morgantown was on May 24th and that they appeared near Cranesville at the eastern borker of Preston county on June 12th and at Helvitia, Randolph Co. (Elevated - ) on June 14.

Whether or not this average difference of $3 \frac{1}{2}$ days for each difference of one degree of average summer temperature will prove to be the rule with all broods and in all seasons, I would not pretend to say, but I trust the readers of this Bulletin will make a careful record of the time of the first general appearance of future swarms in their respective localities, and report the same to the Experiment Station, so that we may be able to arrive at some definite conclusions in the future.

INFLUENCE OF THE WEATHER ON THE APPEARANCE AND DEVELOPMENT OF THE ADULTS.

The period from the middle of May to the middle of June, during which the underground form of the cicada emerges and changes to the aclult was most unfavorable for the appearance of the 1897 swarm, since it was unusually cold and rainy throughout the entire period. This may have somewhat retarded the time of their appearance, but it was noted that while they came out of the ground in greater numbers during the clear and warm evenings, very many emerged when it was cold enough to chill them so they could scarcely crawl, and few were able to extricate themselves from their shells. They were thus easy prey for their numerous natural enemies, such as poultry, birds and predatory insects, among which the common ant was noticed attacking and feeding upon the helpless victims while they were yet alive, while poultry and English sparrows destroyed immense 
numbers of them, and the frequent cold rains must have almost exterminated them in some localities long before the time for their natural disappearance.

VALUABLE AND INTERESTING COMMUNICATION FROM MR. LUTHER HAYMOND.

The record of 102 years, as given by Mr. Haymond, is doubtless the best that has ever been furnished with reference to brood of 1880-97, and since it is from the most reliable source, it gives us great pleasure to present herewith a copy of his letter.

Dear Sir:-

Clarksburg, W. Va., Jan. 18th,1898.

I have recieved your letter of the 14 th inst., asking for such information as I can furnish in regard to the periodical cicada, generally known as the 17 -year locust.

The cicada of this county commenced coming out of the ground on the dates following:

$$
\begin{aligned}
& \text { May } 15,1795 . \\
& \text { May 25, } 1812 . \\
& \text { May 25, } 1829 . \\
& \text { May } 14,1846 . \\
& \text { May 25, } 1863 . \\
& \text { May } 17,1880 . \\
& \text { May } 21,1897 .
\end{aligned}
$$

. The first two dates I procured from my father, the others are the result of my own observation. I was three years and three months of age when the cicada appeared in 1812 , but $I$ do not recollect that I saw them.

The date of their first appearance is inuflenced somewhat by the weather and the temperature. In 1897 , it was cold about the $22 \mathrm{~d}$ of May, and many of them perished. They continued to come up for about two weeks this year, and by the 21 st of June, appeared to have disasppeared in this neighborhood.

I have endeavored to ascertain the extent of this locust district, but have made poor progress. I am informed that they did not appear at Charleston, but were numerous in Nicholas county. They appeared in Meigs county, Ohio. I suppose in this State, that the district does not exteud to the Great Kanawha River, and is bounded by an irregular line north of that river. It is said that they appeared in Grant county in this State. I had previously supposed that this district did not extend east of the Allegheny Mountains. It extends quite extensively . into the State of Ohio. 
As to Pennsylvania, have no information in regard to the cicada. All the harm this inset is properly chargable with is in puncturing the small branches of trees with their ovipositors, to lay their eggs for the next brood in 1914. They do not eat auything and the males do the singing.

In old times there was a superstitious notion that sometimes the cicada had the letters $\mathrm{P}$ and $\mathrm{W}$ on their wings, indicating peace and war, but I find the same characters appear on the wings every year generally resembling the letter $\mathrm{N}$.

I regret that I cannot furnish you with more valuable information, but such as it is I furnish it cheerfully.

Very respectfully,

Luther Haymond.

There is another species of the cicada, considerably larger than the 17 year variety, which appears in August every year, but there is not many of them. They come up out of the ground as the others do, leaving their holes [shell] behind them. How long they live in the ground is a probelm hard to solve. My guess is 20 years.

L. H.

LUCALITIES WHERE THE CICADA WAS REPURTED AS IUST ABUNDANT.

Reports from correspondents indicate that the localities in which the cicada occurred in greatest abundance were in the vicinity of Deepwater and Montgomery, Fayette county: Troy, Gilmer county; Holliday's Cove, Hancock county; Jackson, Elk Fork, Cottageville, Angerona and Grasslick, Jackson county; on hills near Moundsville, Marshall county; and Wheeling, Ohio county; in localities near Ruffalo and McGill; on east side of river from Extra, Putnam county ; near Sassafras, Mason county; Craigsville and Ophelia, Nicholas county; Josiah, Pleasants county ; and on mountains west of Cranesville, Preston county; also near Big Otter and Clay, in Clay county; Kingsville, and Valley Head, Randolph county; Hartley, Ritchie county; McKim, Tyler county; Buckhannon, Upshur county; New Enlgand, Washintgon and Athey, Wood county; Petersburg, Grant county; Bridgeport, Harrison county; Handley, Shrewsbury, Island Branch, Cannelton and Apgah, Kanawha county; Thornburn, Marion county; Oakville and Rion, Roane county; St. George and Texas, Tucker county. 
LOCALITIES WHERE IT WAS MORE NUMEROUS THAN IN FORMER YEARS.

The localities in which the cicada was reported to be more numerous than in former years were near Grasslick, Jackson county: Sassafras, Mason county (reported "thicker than they were ever known by the oldest inhabitants;") Craigsville, Nicholas county; Josiah, Pleasants county; Buckhannon, Upshur county, (where they were "More than in 1880, but not' so many as in 1863;") near Helevitia, Randolph county, (where there were a "few in 1863 , more in 1880 , and a great many more this year,") 1897.

LOCALITIES WHERE IT WAS NOT SO NUMEROUS AS FORMERLY.

Correspondents from Hebron, Pleasants county; New Martinsville, Wetzel county; Flint, Doddridge county; Meighen, (Rosby's Rocks,) Marshall county; Point Pleasant, Mason county, and Edra, Pocahontas county; reported that the locust was not as numerous as formerly.

Places WhERE A FEW WERE OBSERVED.

Congo, Hancock county; Snow Hill and Leivasy, Nicholas county; South Mill Creek, Pendleton county; Traveler's Repose, Pocahontas county.

PLACES WHERE BUT ONE EXAMPLE WAS SEEN OR HEARD.

Bald Knob, Boone county, (observed;) Lewibsurg, Greenbrier county, (observed;) Wayne and Echo, Wayne county, (heard;) and Barnum, Mineral county, (observed.)

PLACES WHERE THE DAMAGE TO FRUIT TREES WAS REPORTED AS GREAT, CONSIDERABLE OR SLIGHT.

Deepwater, Fayette county, two correspondents-one reported that the locust was "killing all of the fruit trees," the other that the "trees were smothered to death with locusts." At MeGill, Putnam county, one correspondents reports that the locust did "great damage to young orchards, and that the limb fell down from being split." Eagle, Fayette county, slight; Sunset, 
Pocahontas county, "killed small peach trees." Troy, Gilmer county, considerable damage; Sherrard, Marshall county, slight.

\section{REVIEW OF INFORMATION OBTAINED BY THE AUTHOR.}

ONE EXAMPLE APPEARED TWO YEARS AHEAD OF REGULAR SWARM.

It is not uncommon for a few examples of a brood to appear one year in advance, or one year after the regular time for the swarm to come forth, but for any member of the brood to come out two years ahead of time is quite an unusual occurrence. I have an example, however, that was taken by my son, Edwin, near our home in Monongalia county, on May 31st, 1895, which could not well belong to any other brood than the one under discussion, unless it should have been one of the last survivors of a disappearing brood, or the representative of a new brood just started. The 1895 brood of the seventeen year race appeared, according to J. B. Smith*, throughout a larger part of Iowa and probably in Illinois and Missouri, but it is not likely that this example could have belonged to this brood. The 1895 brood of the 13 year race also appeared in northwestern Georgia, but it is not possible that it could belong to the thirteenth year race, which has never been recorded so far north. I know of but one other record of the cicada appearing two years before the regular timeł. So it would appear that these early risers deserve to be labeled "record breakers" of the seventeenth year race, or possibly examples of a connecting link between the seventeenth year race of the north and the thirteenth year race of the south.

\section{NONE SEEN OR HEARD IN THE SPRING OF 1896.}

As previously stated, it is common for a few examples to emerge a year in advance of the regular time of their appearance, therefore, in May and June, 1896, I was on the lookout for the

*Smith's economic Entomology, 1896, p. 144.

$\ddagger$ Insect Life, Vol. V., p. 50.-Reported by B. H. Brodnax. 
appearance of the precursors of the 1897 swarms, but I failed to see or hear a single adult. The young or underground form came up quite near the surface in enormous numbers during the month of April, as if preparing to emerge from the ground, but none came out. In taking up sod at the time, I noted that quite a large portion of them were dead and had turned black as if they had died from a disease, which, if so, must have greatly reduced their numbers.

THE SONG OF THE CICADA HEARD IN SEPTEMBER, 1896.

While looking after some timber experiments, on September 26th, 1896, in the mountains some seven miles from Morgantown, in company with Mr. Samuel Sanders, near the home of the latter on Tibb's Run, we distinctly heard the characteristic "f-a-r-r-o" notes of a number of examples of the cicada, and on the following day, I heard one near my home. None were seen, however, so it was only by the characteristic sound that they were identified, yet I feel quite sure they were examples of the true periodical cicada. The only other records I find of the appearance of the insect in the fall, is that of Prof. Lester F. Ward, who stated before the Biological Society, of Washington, that he heard the song of the cicada in October, and of Dr. Fitch who mentioned in his first report, p. 42, that he heard the song of a cicada on September 22, (1854, ) which he thought might have been a straggler from the swarm which appeared in the spring of that year.

\section{NIGHT CONCERTS.}

On two or three nights in June, between the hours of nine and ten o'clock, I heard the cicada singing as vigorously as in the day time. The concert, which lasted but a short time, was apparently started by one or two insects when the others in all directions commenced to sing. I was fortunate enough to hear the starting of one of these night concerts on a clear moonlight night in June. One male in an apple tree near the house suddenly called out as if disturbed or frightened. His neighbors 
in the same tree were thus apparently awakened. One started the familiar song note, which was at once taken up by numbers of the other males, and like the waves from a pebble dropped into still water, the music rapidly spread until it reached the edge of a thick woods, where it was taken by many thousand of singers and the concert was in full blast as it had been the previous day. This continued a few minutes until all had apparently taken part and the sound had reached its highest pitch, when it began to gradually subside, and in a short time silence again prevailed.

\section{A VISIT TO THE BORDER OF THE BROOD.}

On June 23d, Mr. Rumsey and the writer drove through to Cranesville, Preston county, which is near the Maryland line, at an altitude of about 2,600 feet, and some thirty miles distant from Morgantown. During the day's drive, which for the greater part was over mountain roads and through a timbered country, the never ceasing song of the cicada, which in places was almost deafening, became very monotonous. As we approached the eastern border of the county, they became more numerous, and as we ascend the mountain west of Cranesville, we found, at an elevation of about 2,600 to 2,800 feet, the cicada in far great numbers than at any point along our route. The leaves and twigs of the trees along the road were literally covered with the insects, and the twigs were bending from their weight. At this point, which proved to be the eastern border of the swarm, the noise produced by the multiplied thousands of cicada songsters was deafening. As we proceeded a few hundred yards farther up, fewer examples were seen or heard, and by the time the summit was reached, none at all.

From here down the eastern slope and to Cranesville, not a note was heard, and the silence from contrast with the continual din of the day was oppressing. As we returned by another route northward by the road leading to the eastern corner of the State, we met with the border of the swarm a short distance up the southeastern slope of the mountain, and from there on 
to the Pennsylvania line, the cicada was abundant, although not so much as at the border line on the western slope. It would therefore seem quite important that the boundary of this and other broods should be accurately determined and mapped, since if it is the rule for them to occur in great numbers at such places, it will follow that greater damage will be done there. Also where the borders of two or more broods meet and overlap, which they frequently do, and will be shown further on they will appear at shorter invervals and the losses from their injuries to fruit trees will be increased.

FIRST APPEARANCE NEAR MORGANTOWN.

On the hills near Morgantown, at an elevation 1,100 to 1,300 feet, the first adults were observed on May 20th, but it was not until May 24th that the first general appearance of the insect was noted. On this date in the evening, they emerged from the ground in great numbers, * and the next morning, the trunks of the apple trees were covered with their empty shells. This first general appearance was followed by quite cool, rainy weather until the 30th, when there was another general exodus of the pupae from the ground. Under some of the old apple trees, the ground was literally covered with them, and all within a radius of 30 to 40 feet were moving towards the trees as rapidly as their clumsy legs would carry them.

This habit of proceeding from such a distance directly towards the nearest tree, as soon as they emerge from the ground, is a remarkable exhibition of so-called instinct, especially when we take into consideration that nearly seventeen years has elapsed since the young things left the eggs in the twigs of the tree to enter the ground.

Between May 27th and 30th, the first song of the cicada was heard, and by the 9th of June, when they commenced to copulate, the noise made by them was almost deafening.

The females commence oripositing about June 13th and on June 17th, the leaves on the wounded twigs commence to wilt. 
The small variety came out later than the large or normal forms, and among the last pupae that emerged the small ones predominated. Their peculiar note was also heard for some time after that of their larger-brothers had ceased.

By the last week in June all had disappeared except a few stragglers, and after the $4 \mathrm{~h}$ of July, none were heard.

The eggs in twigs I had collected, commenced to hatch on August 20th, and in about a week all the young had apparently emerged.

The eggs in twigs that died soon after they had been attacked did not hatch, especially in those twigs which remained on the tree.

It therefore seems necessary, as other writers have noted, for the eggs to remain in living, or at least moist wood, in order to hatch.

SECONDARY INJURY BY THE WOOLLY APHIS OR WOOLLY LOUSE OF THE APPLE.

On Jan. 20th, 1898, I had some dead and dying apple trees cut down and the dead and diseased branches pruned from others in an old orchard, on a recently purchased farm, and in examining the trunks and branches for evidences of the cause of their deterioration, some interesting and probably new observations were made with reference to the work of the cicada, woolly aphis and tree crickets.

The first thing to attract my attention was the presence of the woolly aphis in the cicada wounds of the living twigs. Knowing that it is the habit of this insect to infest wounds on the trunk and branches of apple trees, and that they not only prevent the wound from healing, but cause an abnormal growth which ultimately results in a serious defect or loss of the injured branch, I realized that the seconclary attack of the aphis on twig injured by the cicada might easily result in serious damage to old as well as young trees. Search was therefore made for old cicada wounds, and abundant evidence was soon found that much of the unhealthy condition of the trees and branches was 
due, principally, to injuries by the periodical cicada, and one of the two species of tree crickets, and secondarily, to the woolly aphis, diseases and other insects.

CICADA WUUNDS SEVENTEEN YEARS OLD.

It has been-supposed that the only injury of any consequence caused by the cicada, was that resulting from their attack on young trees, but it would appear from the evidence found in the condition of the seventeen-year old wounds, on large apple and pear trees, that the losses occasioned from this class of injuries have been underestimated.

f Cicada wounds in the branches of trees which are in a vigorous, growing condition, will rapidly heal, and in a few vears, even the scars may be obliterated, but with recently transplanted trees and fruiting or terminal branches on matured or old ones the condition is quite different. Here the growth is so slow that the wound is not healed the first or second year, but may remain open for many years, or, in the case of terminal branches on old trees, may never heal, even if the branch lives, so that the wounds are exposed year after year, to the attack of the woolly aphis, and deformed, unproductive branches is the result.

Abundant examples of this condition were found in the old orchards referred to, and doubtless any of our readers can find the same thing, who have an old orchard in sections where large swarms of the cicada have appeared within the last twenty years.

OLD CICADA W UNDS IN SUGAR MIPLE

The sugar, or hard, maple appears to be the favorite tree for the cicada to oviposit in, therefore, after I found the old wounds in the apple, I examined a nearby sugar miaple, and found numerous examples of cicada scars on the branches which had made a slow growth. The external appearance of these scars and the curly condition of the wood formed over the wound, are plainly shown in the photograph, Plate II. The curly condition of the wood due to cicada wounds. would indicate that numerous wounds in the main stem of a young seedling maple, 
PLATE II

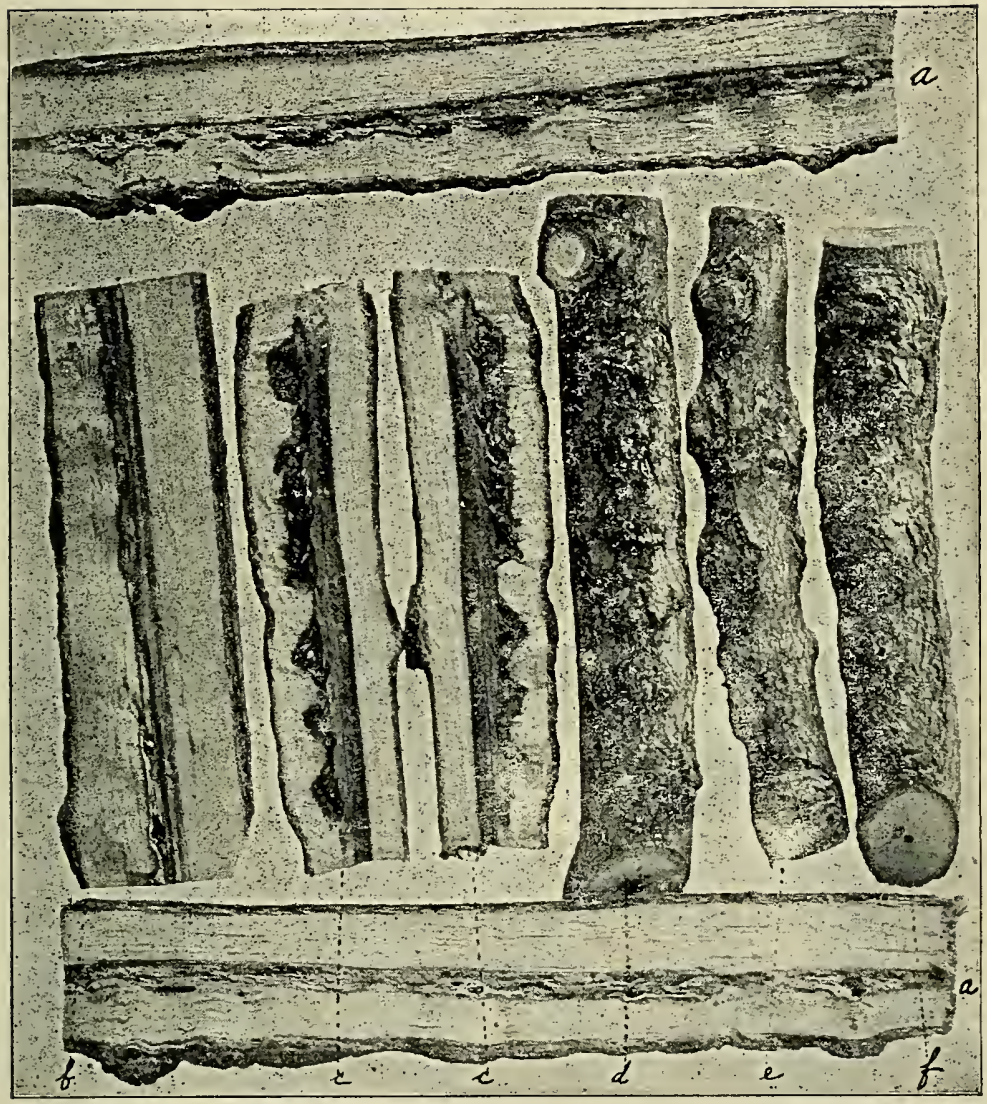

Work of the Periodical Cicada, seventeen years old, in slow growing sugar or hard maple. Showing external scars at $d, e, f$. 

might easily result in a curly condition of the wood in the trunk of a matured tree.

TREATMENT OF OLD TREES INJURED BY THE CICADA.

In the treatment of matured or old trees which have been badly stung by the cicada, the prime objects to be kept in mind are the rapid healing of the wounds and the prevention of secondary attacks by the woolly aphis. The first object may be attained by a severe pruning of the tree during the following winter after the attack was made. All of the severely injured and unproductive branches should be cut out. This will cause renewed vigor to be thrown into the remaining branches, and thus the wounds which are not cut out will soon heal over.

Plowings and cultivating the soil in an old orchard will also stimulate a rapid growth of all parts of the trees.

The treatment of trees injured by the tree cricket is practically the same as that for cicada injuries, except that the twigs and larger branches bearing numerous old, unhealed scars should be cut out, and the unhealed scars on the remaining branches should be filled with hard soap or grafting wax, to prevent the attack of the woolly aphis. The trees should be examined each year, before the leaves start in the spring, and all scars which fail to heal and are infested with the aphis, should be cut out or treated with soap or wax. 


\section{THE 1898 SWARM.}

With a view of obtaining as much additional information as possible regarding the occurance and distribution of this doubtful brood we sent out June 10, 1898, on "reply" postal cards, the following request:

"Will you kindly inform me on the accompanying card, whether or not the periodical cicada ("Seventeenth Year Locust") has been seen or heard in your vicinity this year (1898)? If it has, please state whether it appeared in large or small numbers. Also please give approximate distance and direction from your postoffice of localities in which it occurred."

The replies to this card brought much desirable and interesting information, especially where the insect is recorded from localities where the 1897 swarm did not appear. Where it is recorded from localities within the area covered by the 1897 swarm it is of course impossible to say whether the individual seen or heard were stragglers from the $1897 \mathrm{swarm}$ or belonged to the 1898 swarm, but it would appear from the wide distribution of this brood* that it may possibly occur in any one, or all of the counties of the State.

\section{ORIGIN OF THE BROOD OF THE 17-YEAR RACE.}

It would seem to the writer that this is a very ancient brood and that it might be considered the progenitor of all the other broods of the seventeen races, and that, like primative genera and species, is becoming extinct over a large part of the areas where in early times it may have occured in great swarms. If, as suggested by Marlatt, $\$$ the several broods have originated from the early and later developing individuals of the primative and subsequent broods, it is easy to conceive how all of the broods could have radiated from this widely distributed one.

\footnotetext{
*Bull. 18, new series, U. S. Dept. Agr., viv. Ent., p.62-63. According to the records here given the bruod extends from Eastern New York to Montana in the west, Northern. Wisconsin in the north and to Northern Georgia in the South. Thus it bas the widest range northwest aud south of any brood yel recorded.

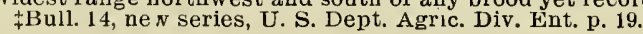


Starting with 1898 and running back through 1897, '96, '95, '94, 93, '92 and '91, it will be seen from records and maps in Division bulletins 14 and 18, previously cited, that this series of broods could have originated from retarded development, while those of 1899,1900 , '01, '02, '03, '04, '05, '06 and '07 might have originated from early developed individuals from the 1898 or subsequent broods.

INFORMATION FROM CORRESPONDENTS, RECORDING POSTOFFICES WHERE THE CICADA WAS OBSERVED OR HEARD IN 1898.

Berkeley :

Martinsburg-Geo. W. Van Metre, June 17: “ * * I have only noticed three specimens." J. N. Thatcher, July 15: "Have noticed four shells of the Periodical Cicada [?] on apple trees in our orchard 5 miles west of Martinsburg.", J. D. Stucky, June 17: " * * heard one or two hollow."

Marlowe-B. F. Wilard, Jnne 19: "I have seen the Cicada in but a single instance this year.",

Tomahawk-Wm. T. Siles, June 21: "The Cicada or locust appeared here in small numbers."

Hedgesville-Wm. L. Cunningham, June 20: "* * heard one and only one a few days ago."

Gerrardstown-W. J. Miller, June 18: "I'he Cicada I have frequently heard during the past two weeks. Have seen none so far."

Little Georgetown-S. L. Dodd, June 20: "I have heard but one, and heard of no others."

Brooke:

Fowlers-R. H. Hunter, June 17: "I have heard some, caught one."'

Fayette:

Spring Dale-T. T. Hurley, July 12: "I have seen oue locust and heard several others this year. I heard of a few in this vicinity about one mile S. S. East of Springdale."

Hico-J. A. Sandige, June 15: "Locusts reported on the 8th inst. * * have entirely disappeared. They were very scattering and only remained about 10 days;" June $20:$ " * * only a very small number was heard commeneing about 1st of June, ending about 10th." " * * they were at Hico P. O. about June 5th, in very small numbers-perhaps only a dozen or so heard"; June 8th: "* * a few locusts have made their appearance iu this locality. Arrived June 1st, but only a very few."

Ellicott-F. D. Reynolds, June 20: “* * I have heard one locust 5 miles west of Ellicott P.O ." 
Graydon-J. F. Kious, July 4: "Probably 6 or 8 locusts heard in this vicinity this year.',

Mountain Cove-L. P. Wills, July 1: "Only a very few of seventeen year locusts have been heard in this section this year." Clay:

Gonld-W. W. Steorts, August 10: "Cicada, seventeen year locust, has been seen and heard in this vicinity this year in small numbers, appeariug about the first of June, about 2 miles north-west postoffice."

Porter-Lee P. Young, June 27th: "Have heard very few. Have not seen any."

Ira-M. Colebank, June 28: "Have heard and seen a few this year; there is nor many to be seen or heard in this locality. Can not hear of any but a few miles south; they have been heard as far east and north from here as twenty miles that I know of."'

Lizemores-C. C. Ellicott, June 25: “ * * the 17 year locust appeared in small numbers; as to locality where they appeared I am not informed."

Grant:

Petersburg-J. D. T., June 27: "* * only heard occasionally." Ilasonville-J. L. Slusher, June 18: "We heard a few locusts in a northeri direction, but did not see any.",

Seymoreville--J. D. Rineheart, June 18: "I have only heard one Cicada and have not heard of any around this jear."

Arthur-Herbert Feaster, June 20: "They have been in very small numbers south west from my postoffice about one mile; also, about one fourth of a mile southeast of my P. O."

Medley-W. J. Babb, June 20: "Have heard but about $\frac{1}{2}$ doz. "Cicada" this season about one mile east of this place. Have not heard them for about a week."

Landes-H. A. Alt, June 23:"** I have heard a single one but have seen none. They were here in large numbers in 1893 . They appeared three miles north of here last year (1897) in large numbers."

Bismark-J. L. Moore, Jnne 21: "** have heard very few of the locusts and seen but one. * * They are a very rare thing on the Allegheny pass, where we live even when they are plenty below the mountains.",

Hancock :

Holliday's Cove-July 20: "The locusts you speak of appeared in two different spots in this locality early in June, but the numbers were small, only a few. Locality two miles east of Holliday's Cove. F. S. Chapman, Jnne 17: "I have heard but one this year. He arrived at the proper time but one year late."

Fairview-D. E. Mayhn, June 23: "I heard one locust sing about 1st June. Saw none." C. W. Beaumont, Jnne 20: "I heard 
one singing in my orchard one half mile south-east from postoffice last reek."

Moscow-Frank S. Eraus, Jnue 22: "I hare heard very few Cicada this year and do not know of any place where they are."

Hampshire:

Romney-John J. Cornwell, June 21: "There are but a few of the Cicada in this section of the country this year." L. A. Corder, June 20: "I have seen locusts in my neighborhood in very limited nos. this year (1898). I have seen about a dozen. Mr neighborhood is eight miles east of Romney."

Capon Bridge--John H. Miller, July 1: "I have heard one of the seventeen year locusts hollow about the first of Jnue. * * The one I heard was about four miles east of Capon Bridge." James W. Horn, June 20: "** my brother informs me that he has heard two or three at our home one mile Trest of post office." Amos L. Pugh. June 18: "The periodical cicada was heard here in very small numbers. * * I heard them several times but saw none.",

Springfleld-O. P. Denmeson, July 2: “* * some say they have heard some this year but very few."

Rio-Simon J. Bowman, June 20: “ * * I have seen and heard the periodical cicada this year but it has been in rery small numbers and the distance is rery limted. I hear this epxression used quite frequently by the people. This is not a locust year here."

Three Churches-R. W. Rives, June 22: "17 year locusts appeared in small numbers 3 miles sonth of this P. O."

Mutton Run-A. A. Brill, June 18: "We had a few locusts this sear, said to be the 13 year kind. Thirteen rears ago we had both kinds."

Kirby-Geo. C. Ludwig, Juue 20: "** there has been but few of the serenteen rear locusts within eight miles of this office in any direction that I have heard of."

Levels-Talbert Dicken, June 18: "There are a few locusis in this vicinity, a few more than commonly appears. This is not their regular year. A sear or two iater thes will make their appearance. What few have appeared this jear appear to be about the same in all directious from here."

Hardy:

Hanging Rock Mills-Hisghman, June 28: “* * a very few of them appeared here about the first of this month but the soon disappeared. * * This locality is about 3 miles S. W. from the above P. O.",

Mathias-S. Emsweler, P. M., June 18: “ * * very few to be heard here this sear."

Inkerman-Wm. H. Davidson. June 1: "None to amount to any thing.", . 
Rockoak-Z. L. Wilson, June 24: "In the year 1885 they were in abundance in both counties-Hampshire and Hardy. Since then (1885) only a few each year appears. I suppose I have heard a $\frac{1}{2}$ doz. this year scattered around."

Jefferson:

Charles Town-Walter Bates, June 18: "The seventeen year locust have not appeared on my farm but have been seen in neighboring places."

Kabletown--L. B. Shntt, June 17: “* * I have noticed only a very few, may be a half dozen in all and never more than one at any one time. Have seen a few of the shells on fences, trees etc. Have noticed no singing. Have covered a radius of six miles in daily travel and have driven as high as forty miles in a day with the same evident scarcity of locusts.",

Halltown-F. Lynch, June 11: "I have heard but one locust this year, seen none, but have inquired of persons in different parts of the Co.; some had heard one or a few, others none. T'he one's voice heard by me sounded like that of a full grown specimen. I live one mile north of Halltown P. O.",

Monroe:

Union-A. S. Johnston, June 27: "I'he Cicada has not appeared in any numbers in this locality this year. In fact $I$ have heard but one or two the entire season thus far, and they in this village. Others tell me they have heard a few, a very few in the outlying directions."

Mason:

Pt. Pleasant- "State Gazette," N. E. Arnold, Mgr., June 17: “The 17 year locust appeared in small numbers in this vicinity some weeks ago, in the locality south-east of postoffice. Did very little damage."

Monongalia :

White Day-John M. Holland: “ * * there has been but two locusts heard in this vicinity this season that I can hear of. One near the White Day P. O. and the other two miles south-east."

Morgan:

Berkeley Springs - H. W. Bayer, June 17: "In respond to your inquiry will say that $I$ heard about $\frac{1}{2}$ doz. periodical cicada on my premises and in my neighborhood approx. $1 \frac{1}{2}$ to $\frac{3}{4}$ miles north-east of postoffice. The flrst I heard was on May 29, 1898, the last about June 2.",

Orleans Cross Roads-J. W. Housroth, June 17: “* * I have heard some few seventeen year locusts this year. But the regular year is not until 1900 in this section."

Marshall:

Cameron-Levi Smith, Ang. 13: "One farmer seven miles south of 
here told me he heard two or three seventeen year locusts in the early summer."

Kansooth-John M. Wingett, June 28: “* * ' there has been very few of them both east, west, north aud south of here."

St. Joseph-M. A. Bicker, June 21: 'I have heard but one periodical cicada in our vicinity this year. About $\frac{1}{4}$ of a mile from St. Joseph P. O., due west."

Glen Easton-R. Butler, June 21: "Have heard two (2) locusts this season one mile south-east of Glen Easton, Mashall Co., W. Va."

Rocklick-B. L. Crow, June 18: “* * I only heard one this year.',

Calis-J. C. Woodruff, Jnne 19: “* * have scarcely been seen in this locality and what were heard were north of this P. O."

Balls- A. E. Hupp, Juue 20th: "The Cicada or (Seventeen year locusts) appeared in small uumbers about oue mile north of Balls. I also heard that they appeared all over southeru Marshall.",

Mineral:

Keyser-J. N. Spencer, Jnne 17: “The cicada appeared in small numbers and stung or killed a few leaves ou the fruit trees. They disappeared ten days ago * * 3 miles due west of Keyser, Mineral Co." E. H. Lillee, June 22: "5 miles south of Keyser a few locusts early in the season.",

New Creek- L. P. Bosley, June 17: "We had a few locusts this year. Appeared about the 4th of June on the east of the Alleghey mountains south-west of New Creek but were never seen east of the creek. Were heard but a few days, they moved southeast towards Laurel Dale and did not extend up the valley auy further than the Graut county line. The space was about 3 miles in leugth and about 4 miles wide."

Ridgeville-Arnold Bros., June 18: “* * They have appeared in this neighborhood but in very limited number. We speak of section north and west of P.O."

Laurel Dale-Edwiu Burgess, June 18: “ * * this year there seems to be a leaving or remuant. I conld in the first of the month hear a solitary one or two wherever I would be, but now I hear no more."

Foote-J. W. Rinehart, June 21: “* * The locusts in this vicinity have made their appearance this year, only in very limited numbers. In 1902 will be the time for their next appearauce here in great swarms."

Patterson's Depot-C. E. Wagoner, June 21: “ * * * the periodical cicada has been heard, but are not numerous, not more than two or three at a time." 
Ohio:

Elm Grove-Lewis Wharton, June 18: “* * * there are a few stragglers from the hoards of 1897. ,'

Clinton-M. L. Connelley, June 20: "* * * This season have not heard them at all and just saw one shell in my orchard where the trunks of the trees were literally covered"'(last year).

Potomac-N. E. Murray, June 18: “* * * I have seen but one this year." John Baird, June 18: "I have heard but one through the season.",

Pendleton:

Sweedlin Hill-P. M., June 22: “ $* *$ * We can hear a few every year."

Macksville-Jacob Narma, June 22: "The cicada is here this year but rare."'

Preston:

Kingwood-J. Slidell Brown, June 17: "Only a few locusts have been heard in this vicinity this year." J. W. White, June 20; "A few cicada (very tew) have been heard here this season.",

Pocahoutas :

Edra-June 24, W. E. Mann: “* * * have seen some in other localities of this county but none in this."

Academy-M. A. Duniap, June 25: “* * * I have heard perhaps a dozen. But there is scarcely a year we do not hear a few. There were more heard here last year. 1901 will be our regular locust year here.",

Raleigh:

Beckley-G. W. Cook, June 20: "The 17 year locust appeared in this section this year in very small numbers, only a straggler here and there.",

Tucker:

Parsous-A. G., July 4: “* $4 *$ * the periodical cicada have been heard in this vicinity in small numbers. They were first heard on the 24 of May, '98, and then at intervals nutil the 1 st inst."

Texas-Elihu Phillips, June 20: "There are but few locust here this year.",

Auvil-Daniel S. Nester, June 20: “ $* * *$ * only a few Cicada were heard in this vicinity this year. * * I also heard some cicada about 1 mile east of Kirt, Barbour county. I heard some $3 \frac{1}{2}$ miles south-west of Auvil, Tncker Co., this year.", Tyler:

Middlebourne-Smith \& Barnes, Eds. "Star" —June 21: “ * * * nor have we seen any one who has seen them in any considerable numbers.", 
Wood:

Parkersburg—"State Journal," June 21: "Farmers from lower end of the county, about seven miles distant, report very few, heard last week.',

INFORUATI IN FROM CIR IESP JNDENTS, RHC RRDING P ST JFFICES WHERE THE CICADA WAS N'T UBSERVED ('R HEARD IN 1898.

Boone

Barbour

Brooke

Berkeley

Clay

Cabell

Fayette

Grant

Haucock

Hardy

Hampshire

Jackson

Jefferson

McDowell

Marion

Mononaglia

Mineral

Marshall

Morgan

Ohio

Pendleton county: Madison.

“ : Philippi.

“ : Short Creek, Wellsburg, Bethany, Fowlers, Miller,

“ : Gerrardstown, Martinsburg, Inwood, Shanghai, Foltz, Beddington, Tabler, Elyria:

“ : Wattsville, Big Otto, Clay.

" : Huntington.

، : Eagle, Cotton Hill, Hawksnest, Sewell, Cliff Top, Oak Hill, Elliott, Maplewood, Powelton, Deepwater, Caperton, Fasetteville, Thurmond.

“ : Falls, Seymourville, Pansy, Martin, Maysville, Gormania, Ketterman, Petersburg, Seemly, Mt. Storm, Bayard, Wilson, Dorcas.

“ : Grant, New Cumberland, Fairview, Pemrith, Holliday's Cove.

، : Moorfield, Lost River, Fabius, Baker, Capon Iron Works, Old Fields.

“ : Dillous, Pleasant Dale, Glebe, Purgitsville, Millbrook, Green Springs.

“، : Ravenwsood.

“ : Duffield, Harpers Ferry, Ripon, Shepherdstown, Kerneysville, Cliarles Town.

“ : Welch.

“ : Fairmont.

“" : Maple, Bowlby, Maidsville, Wadestown.

“ : Elk Garden, Shaw, Schell, New Creek, Blaine, Barnum, Piedmont, Keyser, Burlington, Lanrel Dale, Hartmonsville.

“ : Beelers Station, Moundsville, Graysville, Cameron, Sherrard, Welcome, Thompson, Dallas, Meighen, Rosby's Rock, Wells, Benwood, Sand Hill, Loudensville, Belton.

“ : Orleans Cross Roads, Berkeley Springs, Brosius, Magnolia, Great Cacapon, Cherry Ruu, Holton.

“ : : Elm Grove, Potomac, Clinton.

“' : Franklin, Oak Flats, Ruddle, Shreves, Sugar Grove, Circleville, South Mill Creek, Mouth of Seneca. 
Pocahontas “ : Green Bank, Marlinton.

Ritchie “" : Pennsboro.

Summers " “ : Hintou.

Tucker

“" : Red Creek, Haunahsville, Pleasant Run, Lead Mines.

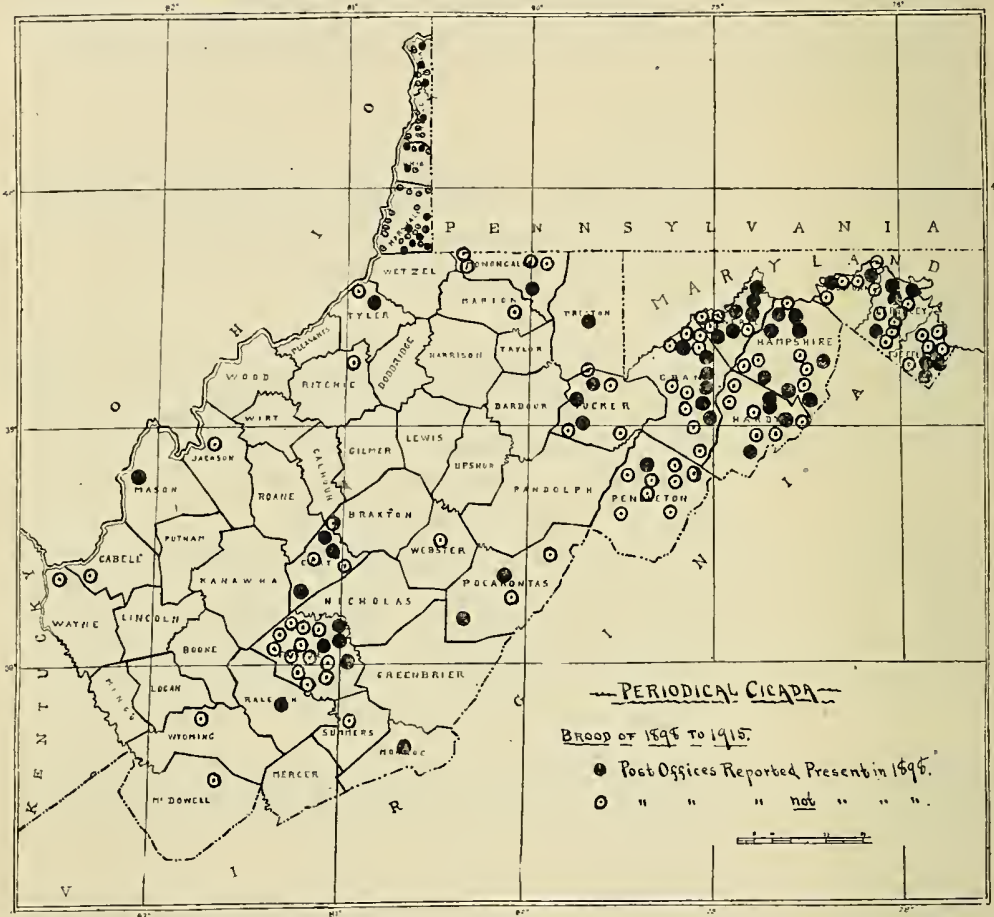

Tyler

Webster

Wayne

Wyoming
" : Sistersville.

"، : Addison.

“: Ceredo, Kenova.

" : Oceana.

THE 1901 SWARM.

Replies from correspondents in 1897 in Mercer, Monroe, Pocahontas, Greenbrier, Raleigh, Summers, Fayette counties and statements by parties living in Randolph and Preston counties, would indicate that this swarm occurs in all of these counties.

Mr. J. J. Echols, of Lewisburg, states: "I think they occur- 
red here in 1884; am told locust year will be in 1899.'-(1901?)

Mr. W. M. Reynolds, of Athens, Mercer county, states: that the locust occurred in 1884 in Mercer "and all the adjacent counties in full force, doing considerable damage to all young orchards."

Mr. C. L. Harvey, writing from Oakvale, Monroe county, says from circumstances, he thinks 1900 will be locust year.

The postmaster at Buckeye, Pocahontas county, states that "locust year in this county will be 1901."

Similar reports were received from Roxie, Sunflower, Prosperity, and Table Rock, Raleigh county ; Clayton, Summer county; and Deepwater, Fayette county.

A Mr. Denton told me that he was positive that locust occurred near Elkins, Randolph county, in 1884, and that they were very numerous. Mr. John Guesman, who lives near Reeds-




ville, Preston county, told me in 1896, that he saw locusts in Monongalia county in 1863, and in Preston county in 1880, and that there was also a 13-year brood in Preston county in 1884. Since we have no 13-year broods in the State, this was evidently the brood of 1884. This would indicate that possibly a spur or detached section of the main body may extend down the valley of Valley river and across into Preston county, which if so, would be very interesting, since it would indicate that it had come through, or over, the high mountains at the head of Valley river by the same route as that by which a detachment of the brood of $1880-97$ passed from this valley into Pocahontas county.

\section{SPECIAL NOTICE.}

It is necessary to call especial attention to this brood, and to warn persons who contemplate the planting of fruit or shade trees this fall or next spring, that there is danger of serious injury or loss of all such trees planted within the area indicated on the map; also to solicit detailed information regarding the exact distribution of the brood and the time of appearance of the swarm in different sections and elevations. See closing paragraphs under "Special Notice to our Readers."

THE 1902 SWARM.

We have little to add from the information obtained from correspondents in 1897-98 except perhaps to indicate more definitely the boundaries of the area occupied.

It will evidently cover all, or the greater part of Jefferson, Berkeley, Morgan, Hampshire and Mineral; the northern part of Hardy; and the northeastern part of Grant counties. It should also be looked for near the eastern borders of Preston, Pendleton, Pocahontas, Greenbrier and Monroe counties, and other counties of the State, since this being such a large brood, it is possible that detached sections may occur almost anywhere in the State. Therefore in order that the exact area may be 


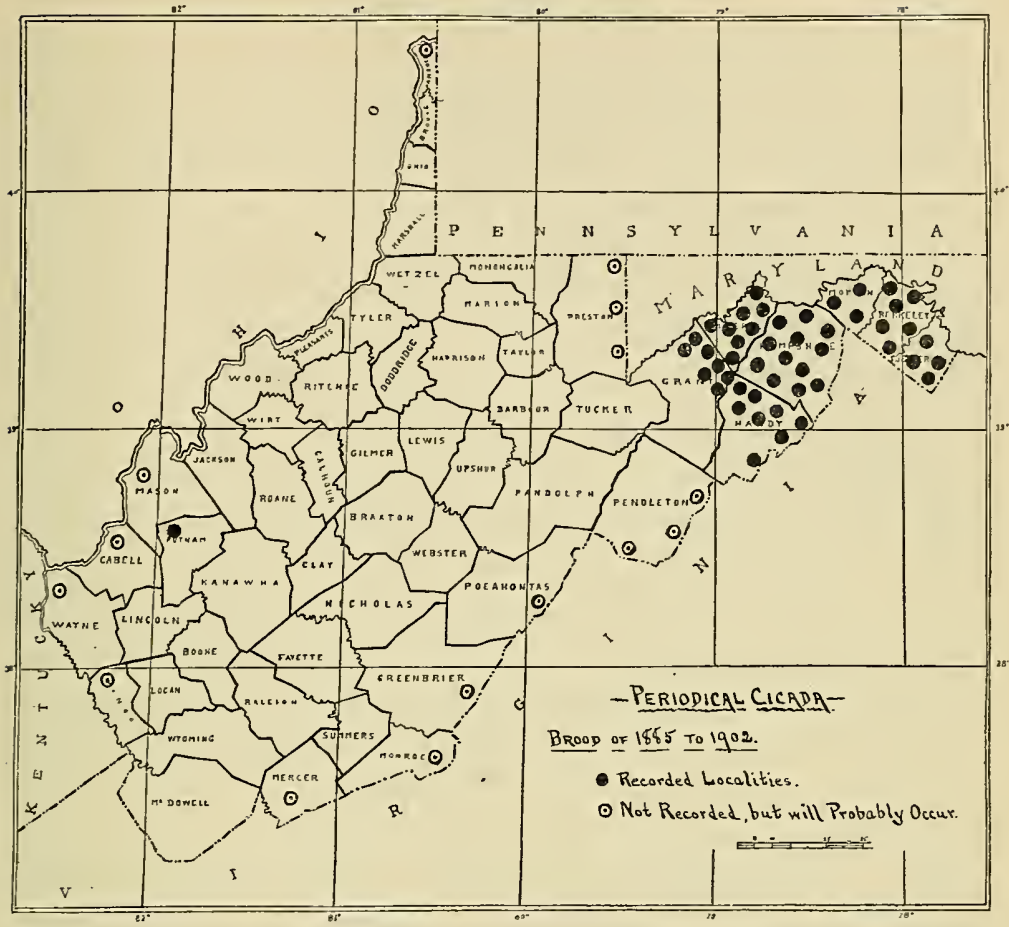

determined the presence of the locust in any part of the State during May and June of 1892 , , should be promptly reported to this office.

This brood is of especial importance, from the fact that it covers the greatest and most promising fruit sections of the State, and that its swarms are said to be unusually dense and destructive. Therefore, it is important for fruit growers to remember that all trees planted between now and June 1902 may be seriously damaged or destroyed, especially when planted in fields that were in forest or orchard in 1895. The fall of 1902 and spring of 1903 will be the time to make extensive plantings of fruit and other trees in all the area occupied by this destructive brood. 
THE 1906 SWARM.

The only additional information to that previously recorded that I can give here is that obtained from Maj. E. A. Bennett, of Huntintgon, Cabell county, whose letter I quote in full: "Replying to your letter about the visitations of the seventeen year locusts, that infested this (Cabell) and adjoining counties in 1889, and were very abundant in the neighborhood of Huntington. I planted a large number of fruit trees in the spring of 1889, in land cleared the previous winter, which fell a prey to the ravages of these insects. I adopted the method of cutting out all limbs that were seriously wounded by them, except that where all of the branches were seriously hurt I cut off all but one or two branches, which were left to support some leaf growth until new shoots could grow, after which those so retained, were, in turn, lopped off. It was found that small limbs and twigs of young trees severely wounded by locusts did not heal and grow, but were utlimately broken off by the winds at the place scared by them. This treatment proved to be the best of several methods experimented with."

Mr. J. C. Livejay, writing from Pliny, Putnam County, states: "There are no locusts in this vicinity below the Kanawha River. Was here about nine years ago."

Mr. Peter S. Couch, writing from Southside, Putnam County states :

"If I remember rightly, it will be about ten years until we have a swarm of then.",

It would appear from the above records and information that the 1906 swarm may be looked for in the western corner of Jackson, throughout Mason, Putnam, Cabell, Wayne and Lincoln and possibly Boone, Logan and Mingo, also in the southern part of Kanawha. It may also join and overlap brood of 1901 in Fayette, Raleigh, Wyoming and McDowell and possibly in the eastern edges of the counties bordering on Virginia, from Monroe to Jefferson, since it is known to extend through Virginia, and to occur in Jefferson county. 
It is recorded in Bull. 14, New Series, Div. Ento. U. S. Dept. Agric. 1898, from Kanawha, Logan and Wood Counties, which would indicate that it may extend through Mason, Jack. son and Wood, along the Ohio River.

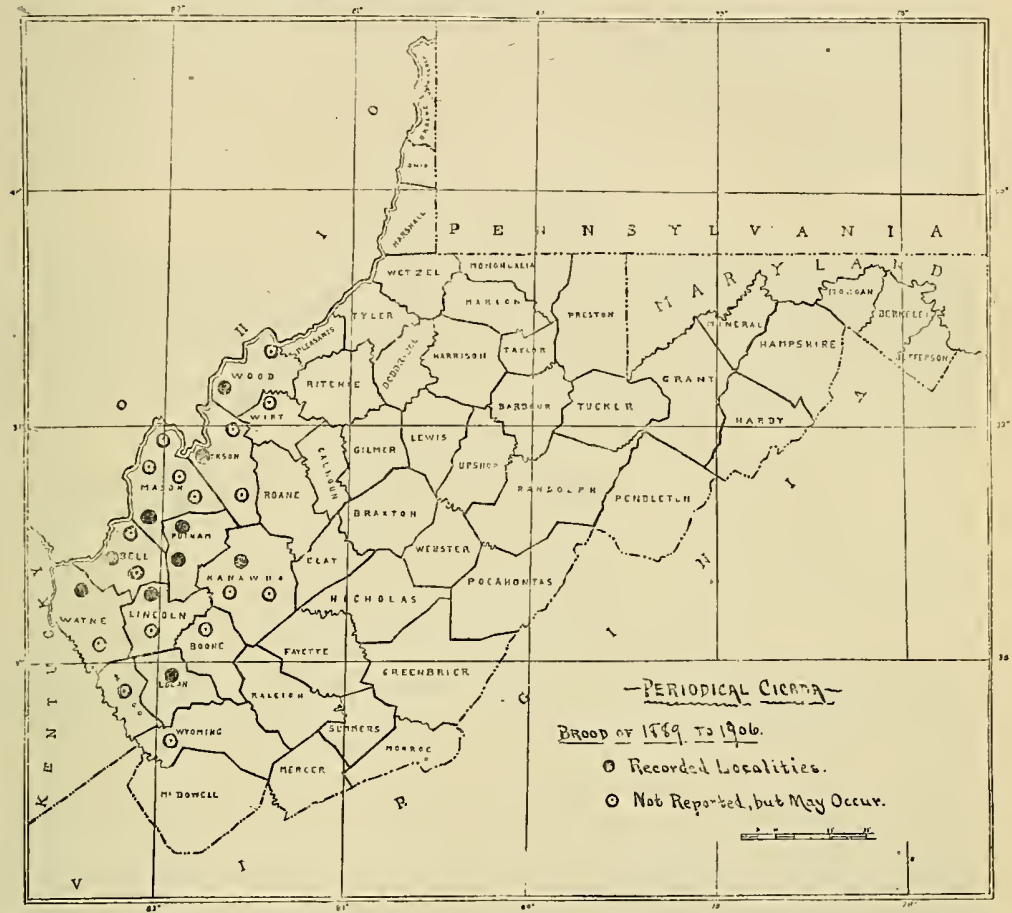

The swarms of this brood are referred to as being very large and destructive, and therefore it is important that information should be sent to the Experiment Station from every postoffice at or near which it appears in 1906.

\section{SECTIONS OF THE STATE WHERE TWO OR MORE BROODS OVERLAP.}

HANCOCK AND BROOKE COUNTIES.

The records indicate that the broods of 1897, 1899, 1899 and 1900 (?) overlap in Hancock and Brooke counties. If so, four 
swarms occur here in four successive years. Then this section will ba exempt thirteen years, until 1914 .

PRESTON COCNTY.

The brood of 1902 may ovrelap 1914 in the eastern border of Preston county and that of 1901 may orerlap 1897 and 1595 in the western part of the county, near Reedsville and Kingwood. So that four swarms may occur in this county-1901, 1902, 1914, 1915 .

\section{JFFFERSON COUNTY.}

The records indicate that the broods of 1893, 1894, 1898, 1901, 1902 and 1906 all overlap in the eastern part of Jefferson county. Therefore the series of Cicada years will be 1901, 1902, 1906, 1910, 1911 and 1915.

\section{MINERAL COUNTY.}

The broods of 1897,1898 and 1902 orerlap in the narrow strip where the 1897 brood crosses the mountain. The next Cicada years in this county will be 1902,1914 and 1915 .

$$
\text { GRANT AND HARDY COCNTIES. }
$$

The broods of 1902 and 1897 overlap in the northern third of Hardy and in the northeastern corner of Grant, while that of $189 S$ overlaps 1897 in the eastern part of both Grant and Hardy. The brood of 1893 occupies the southern part of both counties, and evidently overlaps 1897, while the brcod of 1906 will probably occur in the enstern portion of Hardy. The Cicada may be looked for in 1902, 19C6, 1910, 1914 and 1915.

\section{HAMPSHIRE COUNTY.}

The broods of 1902 and 1895 overlap throughout the greater part of this county and 11 at of 1SC6 and 1893 may extend into the southern and eastern portion, and swarms may be looked for in 1902, 1906, 1910 and 191 .

\section{PENDLETH COUNTY.}

Tha brood of 1993 oceupies the entire county. except, perh us the higher mountain summits. That of 1 S9S has been ricorled from the northern ccmer and it is rossible that the brouls of 1901 and 1903 may extend into this county from ad- 
joining territory in Virginia. Swarms may be looked for in 1901, 1906, 1910, 191อ̃.

\section{RANDOLPH COUNTY.}

The broods of 1897 and 1901 may overlap along the Valley River and adjacent foot hills to the southern border, while that of 1993 may overlap that of 1897 in the ricinity of Day's Mills. Thus, the county probably has three broods, swarms of which may be looked for in 1901, 1910 and 1914.

$$
\text { P CAHONTAS C UNTr. }
$$

The brood of 1897 evidently overlaps that of 1901 in a narrow strip rumning northeast arcoss the middle of the county, the latter brood corering the greater part of the county, while the 1899 brood occurs in small numbers in both the 1897 and 1901 areas. The Cicada years in this county will be 1901, $191 \pm$ and 1910. and possibly 1902, 1906 and 1910.

FAYETTE COUNTY.

The broods of 1897 and 1901 evidently join and overlap in a strip running through the northwestern corner of the county. while those of 1895 and 1901 overalp in the northeastern portion. The Cicada years in this county will be 1901, 1914 and 1915.

KANAWHA COUNTY.

The broods of 1897, 1901 and 1906 probably overlap in the southern corner of the county, and those of 1897 and 1906 in the western corner. so that the Cicada may be looked for in 1901. 1906 and 1914.

PUTNAM COUNTY.

The broods of 1897, 1905 and 1906 probably join and overlap in a rather broad strip running northwest through the county, so that the swarms may be looked for here in 1905, 1906 and 1914.

\section{MASON COUNTY.}

The broods of 1897, 1895 and 1906 evidently join and overlap in a broad belt through the northeastern half of the county. where swarms may be expected in 1906, 1914 and 1915 


\section{JACKSON COUNTY.}

The broods of 1897 and 1906 may join and overalp near the southwestern border, so that the Cicada may be looked for here in 1906 and 1914.

BROOKE, OHIO, MARSHALL, TYLER, WOOD, CLAY, TU'KEK, MONONGALIA COUNTIES.

The broods of 1897 and 1898, if distinct, may overlap in these counties. It is possible, however, that some of the records of 1898 refer to stragglers from the 1897 swarm.

\section{THE STATE.}

The records to date would indicate that there are eight and possibly ten broods of the serenteen year race of the Cicada in West rirginia, and that fron nine to eleven swarms may occur within its borders within the next seventeen years, viz: 1901, 1902, 1905, 1906, 1910, 1911, 1912, 1914, 1915, 1916 and 1917.

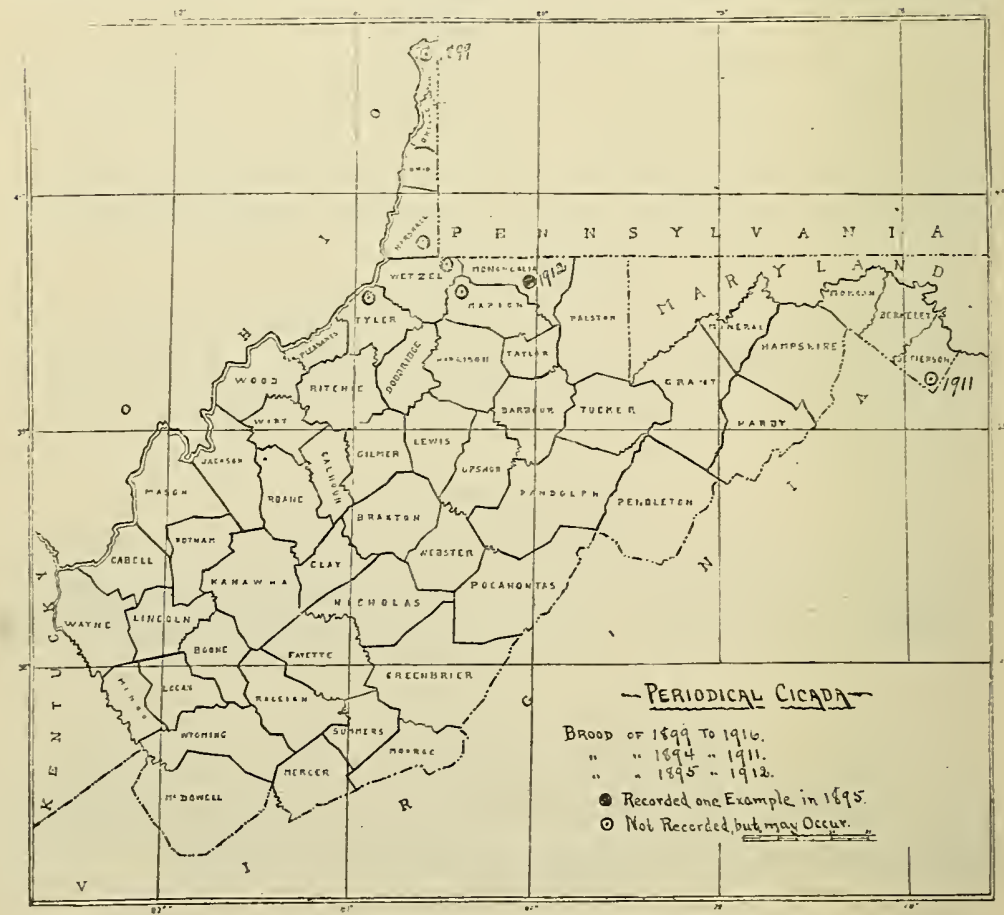




\section{SUMMARY.}

The so-called serenteen year locust is a Cicada, and not a locust, and its proper, common name is Periodical Cicada.

The true locust belongs to a class of insects commonly known as grasshoppers, of which the liocky Mountain locust, or western grasshopper and the Egyptian locust of biblical history are examples.

The Cicada belongs to a class of insects related to the true bugs, all of which take their food through a piercing beak, instead of by means of biting mandables, as do the true locusts.

There are many different kinds or species of insects belonging to the genus Cicada, found in different parts of the world. The common dog-day Cicada, or socalled "jar fly" or "harrest fly," which appears every year in July and August, is a familiar example which differs in size, color and habits from the period. ical Cicada.

The periodical Cicada appears to occur only in the United States. It passes a long period of its existence in the ground, coming out in May and June and changing to the adult or winged form at regular intervals of serenteen and thirteen years. Those that come out in periods of seventeen years are designated as the seventeen year race, and occur only in the northern part of the United States. Those that appear in periods of thirteen years are designated as the thirteen year race, and occur only in the southern part of the United States.

There are many so-called broods of both the seventeen year and thirteen year races, swarms of which appear in different years, and nearly every year somewhere in the United States. There are two varieties as well as two races of the species, one large and the other small. The large variety predominates in the swarms of both races.

The peculiar shrill note of the eicada is produced by the males. The females are voiceless. 
The adult female is provided with a strong, horny ovipositor with which she makes rows of ragged wounds in the living twigs, branches and stems of trees and shrubs in which her eggs are deposited. This often results in serious injury to young orchards, nursery stock, shade trees and ornamental shrubs, also to old apple and pear trees.

With a knowledge of the years in which the swarms are due to appear, and the area occupied by each swarm, almost all losses from injuries to young fruit and omamental trees may be prevented by planting the trees two or three years before or the year after the swarm appears

In West virginia eight broods have been recorded, five of which are known to appear in destructive swarms. Each brood occupies a separate section of the State, except that they join and overlap.

Swarms of each brood appear at regular intervals of seventeen years, hence all belong to the seventeen year race. The thirteen year race has never been recorded authentically in West Virignia.

The years in which the swarms of the different broods are due to appear in their respective sections of the State are: 1901, 1902, 1905, 1906, 1910, 1911 (?), 1912, (?) 1914, 1915. 1917.

The counties in which swarms of the Cicada may be looked for are as follows:

The 1901 swarm may be looked for in Raleigh, Fayette, Summers, Mercer, Monroe, Greenbiier; Pocahontas, Randolph, Tucker (?), Preston (?), McDowell (?), Wyoming (?), Logan (?,) Boone (?,) Kanawha (?), Nicholas (?). May be expected in destructive numbers in some localities.

The 1902 swarm may be looked for in Jefferson, Berlicley, Morgan, Hampshire, Mineral, Hardy, Grant, Preston (?), Pendleton (?), Pocahontas (?). Will doubtless appear in very destructive numbers in certain localities.

1905 swarm may be looked for in Putnam, Lincoln (?), 
Kanawha (?), Mason (?), and Cabell (?), and will probably appear in destructive numbers.

The 1906 swarm may be looked for in the counties of Mason, Cabell, Putnam, Lincoln, Wayne, Boone (?), Logan(?), Mingo(?), Wyoming (?), McDowell (?), Raleigh (?), Favette (?), Kanawha (?), Jackson (?). This will be in all probability a very destructive swarm.

The 1910 swarm may be looked for in the counties of Pcndleton, Hardy, Grant, l'andolph, Pocahontas (?), Greenbrier (?), Monroe (?), Wayne (?), Mingo (?).

The 1914 swarm may be looked for in the county of Barbour, Brooke, Braxton, Clay. Calhoun, Doddridge, Fayette, Gilmer, Grant, Hancock, Hardy', Harrison, Jackson, Kanawha, Lewis, Marion, Marshall, Mason, Mineral, Monongatia, Nicholas, Ohio, Preston, Putnam, Pocahontas, Pleasants, Roane, R'andolph, Ritchie, Taylor, Tyler, Tucker, Upshun, Wetzel, Wirt, Wood, Webster, Wayne (?), Summers (?), Boone (?), and Greenbrier (?). This is the largest swarm and will doubtless occur in destructive numbers in certain localities.

The swarm of 1915 may be looked for in all of the counties of the State, but it is not likely to occur in any locality in sufficient numbers to do any harm or even attract especial attention.

The swarm of 1917 may be looked for in Hancock and northern part of Brooke counties, where it may occur in large numbers.

The first general appearance of a swarm will vary from the 10th of May to the 15th of June, owing to difference in seasons, latitude and elevation. There appears to be a difference of $3 \frac{1}{2}$ days in first general appearance for each difference of 1 degree $F$ in normal or average summer temperature.

The species aprear to be confined in its distribution to the upper austral and transition life zone areas, and probably does not occur in the Canadian zone, which in West Virginia, is at and above an elevation of 2,500 feet above the sea.

A few individuals of a swarm may appear one and even two 
years before the regular time. A few may come out in the fall of the 16th year, and some stragglers may appear in the spring or fall of the 1Sth year, but the swarm of each brood appear at regular intervals of 17 years.

The English sparrow is one of the worse enemies of the periodical Cicada, and appears to be exterminating it in the neighborhood of towns and cities.

Hogs root the young forms out of the ground in the Spring of the $16 \mathrm{th}$ and $17 \mathrm{th}$ years, and where the insects are abundant fatten on them.

Poultry destroy immense numbers of the young as they come from the ground and the immature adults as they cling to the trunks of trees, weed stems, etc.

Squirrels are said to fatten on the adults.

Numerous predatory and parasitic insects prey on the eggs, young and adults.

Contagious diseases often take the character of an epidemic and apparently exterminate the insect, over large areas.

HOW TO AVOID LOSSES FRON CICADA INJURIES TO FRUIT AND OTHER TREES.

Before purchasing trees or shrubs for planting, consult the Cicada map, and if there is a possibility of a swarm of the Cicada appearing in your county within the next two years, ascertain if it was common in the locality where the trees are to be planted, or if the land was in woods, sprouts, or briars during the last Cicada year. If so, put off planting until the fall or spring after the swarm is due.

Never plant orchards in the fall previous to a Cicada year, or in the spring of the year the Cicada is due to appear in the locality.

If planting has already been done and the Cicada makes its appearance in threatening numbers, it may be practicable to protect a limited number of small trees and shrubs by covering the tops with thin muslin, or mosquito netting during the first three reeks in June.

If all of the above precautions have been neglected, and 
young or old trees are severely injured, cut out all severely injured branches, or in case of the trunks of young fruit trees being badly wounded and the tree does not die before fall, cut it off just above the point where the tree is budded or grafted, so that new and vigorous sprouts may be started.

If our readers will kindly report all appearances of the periodical Cicada in the vicinity of their respective postoffices, in any year between and including 1901 and 1916, it will enable the entomologist to prepare and publish accurate maps, showing the distribution of each brood, which will be of special value to the fruit growers.

\section{SPECIAL INFORMATION DESIRED REGARDING THE 1901 SWARM.}

Accurate information is especially desired from all sectinns of the state as to whether or not the Cicada is seen or heard during May and June 1901. Every reader of this bulletin will confer a great favor, and contribute to a better knowledge of some important facts relating to the habits of this insect if they will make a special note of the exact dates on which the Cicada commences to emerge, and begins to sing, in the vicinity of your home or postoffice, as well as the direction and distance from postoffice, and whether in valley or on slopes or summits of hills or mountains. 



\section{NOTICE.}

Application for bulletins of this Station should be adressdd to the Director of the West Virginia Agricultural Experiuent Station, Morgantown, W. Va.

(The bulletins named below are available for distribution.)

No. 4. The Creamery Industry; Its Adaptability to West Virginia.

No. 5. The Selection of Milch Cows.

No. 6. Six Month's Experience in Running a Creamery, Improved Process of Handling Cream and Churning.

No. 12. The Canada Thistle.

No. 14. Farm and Garden nsects and Experiments with Remedies; Note of the Season.

No. 15. Raspberry Gouty-Gall Beetle.

No. 16. Yellow Locust, Insect Ravages upon.

No. 17. Black Spruce, Insect Ravages.

No. 19. Your Weeds and Your Neighbor's Part 1. Weeds as Fertilizers.

No. 20. Potato Culture and Fertilization. Tests of Some Varieties of Tomatoes.

No. 21. Injurious Insects and Plant Diseases.

No. 25. Plat Experiments with Commercial Fertilizers on Wheat.

No. 26. Inspection of Commercial.Fertilizers.

No. 27. Notes on Pruning.

No. 28. Plat Experiments with Commercial Fertilizers on Corn.

No. 29. Experiments with Potatoes at the Station. Experiments on Corn at the Out-Stations.

No. 30. Address and Notes on Sheep.

No. 33. Sub-rrigation in the Green House.

No. 38. Potato Blight, Potato Scab.

No. 40. Commercial Fertilizers.

No. 42. Vegetables.

No. 43. When, Why, What and How to Spray 
No. 44. Practical Entomology.

Special Bulletin No. 2. Proceedings connected with the celebration upon the completion of the Station Building and the organization of the Sheep breeders and Wool-Growers' Association and the State Horticultural Society.

Third Anunal Report, 1890.

No. 51. Commercial Fertilizers, Jan. '98.

No. 52. Strawberries.

No. 53. Commercial Fertilizers, Deec. '98.

No. 54. Nursery Hints.

No. 55. Sugar Beets.

No. 56. Report on Investigations to Determine the Cause of Unhealthy Conditions of the Spruce and Pine From 1880-1893.

No. 57. Commercial Fertillizers.

No. 58. The Effect of Pressure in the Preservation of Milk

No. 59. Whole Corn Compared with Corn Meal for Fattening Hogs.

No. 60. Poultry Experiments.

No. 61. Sheep Feeding Experiments.

No. 62. A Study of the Effects of Incandescent Gas-light on Plant Growth.

No. 63. Commercial Fertilizers, 1899.

No. 64. Sugar Beet Investigation in 1899.

No. 65. Commercial Fertilizers.

No. 66. Fruit Diseases and How to Treat Them.

No. 67. 'The Hessian Fly in West Virginia. 

